2001

\title{
The Foreign Affairs of Federal Systems: A National Perspective on the Benefits of State Participation
}

Daniel Halberstam

Follow this and additional works at: https://digitalcommons.law.villanova.edu/vlr

Part of the Constitutional Law Commons

\section{Recommended Citation}

Daniel Halberstam, The Foreign Affairs of Federal Systems: A National Perspective on the Benefits of State Participation, 46 Vill. L. Rev. 1015 (2001).

Available at: https://digitalcommons.law.villanova.edu/vlr/vol46/iss5/4

This Symposia is brought to you for free and open access by Villanova University Charles Widger School of Law Digital Repository. It has been accepted for inclusion in Villanova Law Review by an authorized editor of Villanova University Charles Widger School of Law Digital Repository. 


\title{
THE FOREIGN AFFAIRS OF FEDERAL SYSTEMS: A NATIONAL PERSPECTIVE ON THE BENEFITS OF STATE PARTICIPATION
}

\author{
Daniel Halberstam*
}

\section{INTRODUCTION}

$I^{N}$ $\mathrm{N}$ recent years, the constitutional law of foreign relations has come under intense academic scrutiny, and with it the traditionally accepted constitutional balance between the federal government and the States. ${ }^{1}$ In the course of this renewed debate, revisionist scholars have challenged the previously dominant view that States have no place in foreign affairs. ${ }^{2}$

* Assistant Professor of Law, University of Michigan Law School. I would like to thank David Barron, Donald Herzog, Rick Hills, Ellen Katz, Alisa Klein, Richard Primus, Nigel Purvis, Donald Regan, Peter Spiro, and Edward Swaine for valuable comments and discussions, and Lumen Mulligan and David Peters for helpful research assistance. I would also like to thank the University of Michigan Law School for providing generous research support from the Cook Endowment.

1. See generally Bruce Ackerman \& David Golove, Is NAFTA Constitutional?, 108 Harv. L. Rev. 799 (1995); Curtis A. Bradley, A New American Foreign Affairs Law? 70 U. Colo. L. Rev. 1089 (1999) [hereinafter Bradley, A New American Foreign Affairs Lawu?]; Curtis A. Bradley, The Treaty Power and American Federalism, 97 MicH. L. Rev. 390 (1998) [hereinafter Bradley, Treaty Power]; Curtis A. Bradley \& Jack L. Goldsmith, Customary Intemational Law as Federal Common Law: A Critique of the Modern Position, 110 Harv. L. Rev. 815 (1997); Jack L. Goldsmith, Statutory Foreign Affairs Preemption, 2001 Sup. CT. Rev. 175 [hereinafter Goldsmith, Statutory Foreign Affairs Preemption]; Jack L. Goldsmith, Federal Courts, Foreign Affairs, and Federalism, 83 VA. L. REV. 1617 (1997) [hereinafter Goldsmith, Federal Courts]; David M. Golove, Treaty Making and the Nation: The Historical Foundations of the Nationalist Conception of the Trealy Power, 98 Mich. L. Rev. 1075 (2000) [hereinafter Golove, Treaty Making]; Harold Hongju Koh, Is International Law Really State Law?, 111 HARv. L. Rev. 1824 (1998); Michael D. Ramsey, The Power of the States in Foreign Affairs: The Original Understanding of Foreign Policy Federalism, 75 Notre Dame L. Rev. 341 (1999); Peter J. Spiro, Foreign Relations Federalism, 70 U. Colo. L REv. 1223 (1996) [hereinafter Spiro, Foreign Relations Federalism]; Edward T. Swaine, Crosby as Foreign Relations Latu, 41 VA. J. INT'L L. 481 (2001) [hereinafter Swain, Foreign Relations Law]]; Edward T. Swaine, Negotiating Federalism: State Bargaining and the Dormant Treaty Power, 49 Duke L.J. 1127 (2000) [hereinafter Swain, Negotiating Federalism]; Laurence H. Tribe, Taking Text and Structure Seriously: Reflections on Free-Form Method in Constitutional Interpretation, 108 HARv. L. Rev. 1221 (1995); Mark Tushnet, Globalization and Federalism in a Post Printz World, 36 Tulsa L.J. 11 (2000); G. Edward White, Observations on the Tuming of Foreign Affairs Jurisprudence, 70 U. CoLo. L. Rev. 1109 (1999); John C. Yoo, Globalism and the Constitution: Treaties, Non Self-Execution, and the Original Understanding, 99 Colum. L. Rev. 1955 (1999).

2. See, e.g., Bradley \& Goldsmith, supra note 1 , at 815 (arguing that state courts may play legitimate role in adjudication of customary international law); Goldsmith, Federal Courts, supra note 1, at 1677 (arguing that absent congressional action broad judicial displacement of state authority in this area is unwarranted both as matter of constitutional interpretation and institutional competence); Spiro, Foreign Relations Federalism, supra note 1, at 1225 (arguing that exclusion of States from foreign affairs arena is no longer justified in post-war era of more discriminating global interactions). 
The dominant focus of this revisionist challenge is that state involvement in foreign affairs is not as hazardous as has previously been assumed. ${ }^{3}$ For example, on the revisionist view, foreign states have become more sophisticated in fine-tuning retaliation to affect not the Nation as a whole, but the responsible subnational unit of government; the end of the Cold War defused the tinder-box of international relations in which any diplomatic misstep implied apocalyptic consequences; and the federal political actors are, in any event, capable of containing adverse state action without the help of the judiciary. Although there is disagreement about these claims, the debate thus focuses largely on the existence and mitigation of adverse consequences of States, foreign affairs activities to the Nation as a whole. ${ }^{4}$

Prior commentary suggesting greater openness to States' foreign affairs activities has accordingly argued primarily from the perspective of state autonomy, by challenging the constitutional warrant for limiting what would otherwise be a legitimate domain of state activity and by reassessing the harm that States may inflict upon the Nation. By contrast, this Article considers the potential advantages to the Nation of state involvement in foreign affairs. Finding that such advantages exist, it examines how state activities might be harnessed to reap them. Such considerations will not inform the debate surrounding any state autonomy interest in foreign affairs, but suggest that even if only national interests should bear on foreign affairs analysis, certain state involvement might nonetheless be valuable for the Nation as a whole. ${ }^{5}$ And if so, a slightly

3. See, e.g., Goldsmith, Federal Courts, supra note 1, at 1698 (noting that although "threat of fifty different voices" in foreign affairs looms large, there is "little reason to think that state control over matters not governed by enacted federal law affects U.S. foreign relations in a way that warrants preemption"); see also id. (stating that federal political branches "are quite capable of identifying and responding to any adverse consequences of this behavior").

4. See, e.g., Spiro, Foreign Relations Federalism, supra note 1, at 1253 (challenging Goldsmith's assumption that federal political branches are able to control States' harmful behavior); id. at 1259-61 (arguing instead that harm is minimized today because foreign nations recognize States as "demi-sovereigns" and are likely to target retaliation not at U.S. at large, but against offending State in particular); Swaine, Negotiating Federalism, supra note 1, at 1254 (noting difficulty of assessing whether federal government is able to contain dangers of state involvement). Scholars have made reference to the potential benefits of state involvement only in passing. See, e.g., Bradley, A Newv American Foreign Affairs Lawu?, supra note 1, at 1099; Goldsmith, Slatutory Foreign Affairs Premption, supra note 1, at 190-91. Even these authors do not focus on the national benefits as a means to evaluate the States' participation in foreign affairs. See, e.g., Goldsmith, Statutory Foreign Affairs Preemption, supra note 1, at 177 ("Should preemption analysis indulge a presumption in favor of the federal government? Should it instead be biased to protect traditional state prerogatives? Or should no presumption attach in either direction?").

5. Professor Spiro does indicate that "internationalists" should embrace state and local activity in foreign affairs, because it "should advance the cause of international law." Spiro, Foreign Relations Federalism, supra note 1, at 1268 . The suggestion made in this Article, in contrast, is that certain forms of subnational involvement in foreign affairs are in the interest of the United States. 
different lens emerges through which to examine the limits that might be imposed on state involvement in the interests of the Nation.

The occasion for these reflections is the Supreme Court's decision last Term in Crosby v. National Foreign Trade Council, ${ }^{6}$ in which the Court held that a federal statute preempted a Massachusetts public procurement law barring purchases from suppliers doing business in Burma. In so doing, the Court refrained from holding broadly that the Constitution categorically excludes the States from the foreign policy arena, or even that the Constitution gives rise to a presumption against such state involvement. Instead, the Court took pains to insist that its displacement of state law was merely the result of a careful reading of the federal statute.

This Article will argue that Crosby is consistent with a recognition of the national benefits of state involvement in foreign affairs and the view that States may participate in foreign affairs to the extent these benefits are realized. It will present the recent history of state participation in foreign affairs to illustrate the States' deep involvement in foreign policy matters and to present the many potential benefits thereof. To enrich our understanding of the potential benefits of subnational involvement in foreign affairs, it will briefly consider similar involvement of component states in the European Union and Germany. Drawing on this parallel experience, this Article will suggest that one major benefit of component state involvement in foreign affairs is overcoming bureaucratic inertia at the central level of governance. The Article then explores the doctrinal consequences for the United States of an approach centered around this recognition: States should not be excluded from the foreign policy arena, States must not discriminate against their sister States in the pursuit of foreign policy objectives, and any positive federal policy as articulated by the political branches should be vigorously protected.

The following contribution to this Symposium will accordingly begin (in Part II.A.) by describing the Court's decision in Crosby. It will then (in Part II.B.) turn to the history of judicial concern about state involvement in foreign affairs, which the Court's opinion in Crosby carefully avoided. Part III will then review States' activities in the foreign affairs arena over the past thirty years. It will demonstrate that States have been deeply engaged and, indeed, increasingly active in foreign policy matters ranging from trade and investment issues to more "purely political" concerns. Apart from demonstrating States' increased presence on the international scene, this part will conclude that foreign affairs are difficult to distinguish from domestic matters and that States may play several positive roles in the Nation's conduct of foreign affairs. Part IV, in turn, describes how the federal government has indeed recognized some of the benefits of state participation in foreign affairs, and how it has sought to include the States in an important area of foreign policy making: international trade regulation. Part $\mathrm{V}$ adds a comparative perspective as a means to assist our under-

6. 530 U.S. $363(2000)$. 
standing of the potentially positive aspects of component state participation in foreign affairs. After briefly discussing the experience of the European Union (Part V.A.) and Germany (Part V.B.) in which subnational participation in the governance of the system as a whole is mitigated by a duty of fidelity to the common enterprise, this Part discusses three potential conceptions of subnational support of the national interest that might inform our approach in the United States (Part V.C.). Part VI then explores the doctrinal consequences of an approach that specifically seeks to preserve the potential benefits to the Nation of state participation in foreign affairs. Part VII briefly returns to Crosby and presents two readings of the case, one of which is compatible with the approach fleshed out in Part VI. Part VIII provides a brief conclusion.

\section{The Court's Decision in Perspective}

\section{A. The Court's Opinion in Crosby}

At issue in Crosby was the constitutionality of a 1996 Massachusetts law enacted in response to human rights abuses in Burma, barring state entities from purchasing goods or services from suppliers doing business in that country. ${ }^{7}$ A coalition of companies doing business in Burma brought suit charging that the state law was unconstitutional in that it infringed upon the federal foreign affairs power, contravened the Foreign Commerce Clause and was preempted by a federal statute enacted three months after the state law had been passed. That federal act ("Act") set forth a detailed scheme for imposing federal sanctions on Burma. ${ }^{8}$ It restricted U.S. aid to Burma, denied support for any international aid to the country, ${ }^{9}$ and severely limited the entry of Burmese officials into the

7. See Mass. Gen. Laws Ann. ch. 7, \$ 22G-L (West 2000). The law contained exceptions in the case of essential goods or services where the exclusion of a party that otherwise met the criteria for exclusion would render the bidding uncompetitive or in the absence of other bidders. See Mass. Gen. Laws AnN. ch. 7, $\S 22 \mathrm{H}(\mathrm{b})$ (1) \& (2), (d) (West 2000). It also excepted the media, Mass. Gen. Laws AnN. ch. $7, \S 22 \mathrm{H}$ (e) (West 2000), and essential medical supplies when no alternative supplier existed, MAss. GEN. LAws ANN. ch. 7, § 22I (West 2000).

8. See Foreign Operations, Export Financing, and Related Programs Appropriations Act, 1997, Pub. L. No. 104-208, 110 Stat. 3009 (enacted by the Omnibus Consolidated Appropriations Act, 1997, § 101 (c), 110 Stat. 3009-121 to 3009-172).

9. The Federal law also directed Executive Branch officials to vote a certain way in international institutions, a potentially unconstitutional usurpation of the President's powers. Id. at $\$ 570$ (c)(2) ("The Secretary of the Treasury shall instruct the U.S. executive director of each international financial institution to vote against any loan or other utilization of funds of the respective bank to or for Burma."). For a discussion of the ambiguities of the congressional-Executive relationship with regard to U.S. participation in international organizations and the use of "voice and vote" provisions in various contexts, see Charles Tiefer, Adjusting Sovereignty: Contemporary Congressional-Executive Controversies About International Organizations, 35 TEx. INr'L L.J. 239, 251 (2000) (noting that Clinton Administration had not opposed attempts to impose "voice and vote" provisions, but that earlier administrations had done so on grounds that such provisions encroached on executive power). 
United States until the President certified to Congress that Burma made "measurable and substantial progress" toward safeguarding democracy and human rights. The Act also authorized the President to prohibit "U.S. persons" from making any "new investment" in Burma, and directed the President to work with members of various international organizations towards "a comprehensive, multilateral strategy to bring democracy to and improve human rights practices and quality of life in Burma." 10

The District Court sided with the plaintiffs, finding that the state law "unconstitutionally impinge[d] on the federal government's exclusive authority to regulate foreign affairs." 11 The Court of Appeals affirmed that judgment, holding against the State separately on each of the three arguments originally set forth. It found that the law was an unconstitutional interference with the federal government's power to conduct foreign affairs under Zschernig v. Miller, ${ }^{12}$ contravened the dormant Foreign Commerce Clause, ${ }^{13}$ and was preempted by the federal act. ${ }^{14}$ The Supreme Court affirmed. ${ }^{15}$

Justice Souter's opinion for the Court carefully avoided discussing the first two claims, and instead affirmed solely on the ground that the state law conflicted with the federal act. First, the Court held that the additional state sanctions undermined congressional intent to "provide the President with flexible and effective authority over economic sanctions against Burma." 16 Congress authorized the President to terminate existing sanctions, as well as impose new sanctions, after certifying to Congress the existence of various conditions. Indeed, the Act authorized the President to terminate all sanctions upon certifying that their imposition ran counter to U.S. national security interests. Upon reviewing this scheme, the Court deemed it "simply implausible that Congress would have gone to such lengths to empower the President if it had been willing to compromise his effectiveness by deference to every provision of state statute or local ordinance that might, if enforced, blunt the consequences of discretionary Presidential action."17

Second, the Court found that the State's sanctions compromised Congress's clear intent to "steer a middle path" in the imposition of sanc-

10. Several months after the law was enacted, the President made the determinations necessary to impose additional sanctions, and ordered a halt to "new investment" on the part of "U.S. persons." Exec. Order No. 13,047, $\$ 1$ (May 20, 1997), 3 C.F.R. 202 (1997). 1998).

11. Nat'l Foreign Trade Council v. Baker, 26 F. Supp. 2d 287, 291 (D. Mass.

12. 389 U.S. 429 (1968); see also Nat'l Foreign Trade Council v. Natsios, 181 F.3d 38, 52-55 (1st Cir. 1999).

13. U.S. Const. art. I, $\$ 8$, cl. 3; see also Natsios, 181 F.3d. at 61-71.

14. See Natsios, 181 F.3d at 71-77.

15. See Crosby v. Nat'l Foreign Trade Council, 530 U.S. 363 (2000).

16. Id. at 379.

17. Id. at 376 . 
tions. ${ }^{18}$ The federal act, for example, authorized a ban on "new investment," a term that Congress carefully defined to exclude, among other things, "contract[s] to sell or purchase goods, services, or technology." 19 The state law, in contrast, was far more general in its sweep, prohibiting all state purchasing from companies doing business in Burma. ${ }^{20}$ That the state and federal laws were ostensibly pursuing the same goal did not pertain. The Court explained that "[s]anctions are drawn not only to bar what they prohibit but to allow what they permit," and held that "the inconsistency of sanctions here undermines the congressional calibration of force." ${ }^{1}$

Finally, the Court noted that the Massachusetts law frustrated Congress's intent to confer control over all U.S. sanctions against Burma upon the President and thereby to enable him to work with foreign leaders and international institutions on a "comprehensive, multilateral strategy" for improving the situation in Burma. ${ }^{22}$ In other words, the Congress conferred upon the President certain powers over foreign commerce in addition to whatever foreign affairs powers the President may have already had under the Constitution alone. The Congress thus consolidated federal power with regard to Burma sanctions in the President and thereby expressly empowered him to take the lead for the Nation on the issue of Burma in the international community. The Massachusetts sanctions threatened this scheme by diffusing control over sanctions, thus impeding the President's "capacity ... for effective diplomacy." ${ }^{3}$ As the opinion notes, "[i]t is not merely that the differences between the state and federal Acts in scope and type of sanctions threaten to complicate discussions; they compromise the very capacity of the President to speak for the Nation with one voice in dealing with other governments." 24 Because Massachusetts' Burma sanctions ran contrary to the federal act, the Court declared the state law preempted, and thus unconstitutional under the Supremacy Clause.

18. $I d$.

19. 110 Stat. at 3009-3167.

20. The law contained exceptions in the case of essential goods or services where the exclusion of a party that otherwise met the criteria for exclusion would render the bidding uncompetitive or in the absence of other bidders. See Mass. Gen. Laws AnN. ch. 7, $\$ 22 \mathrm{H}$ (b) (1) \& (2), (d) (West 2000). It also excepted the media, MAss. Gen. LAws AnN. ch. 7, \$22H(e) (West 2000), and essential medical supplies when no alternative supplier existed, MASs. GEN. Laws ANN. ch. 7, \$221 (West 2000). Apart from these exceptions, however, the state law reached more broadly than the federal act.

21. Crosby, 530 U.S. at 380 .

22. Id. at 364 .

23. Id.

24. The Court found further evidence for this in the formal protests against the Massachusetts law that have been lodged by U.S. allies in Washington, D.C., the European Union's (EU) and Japan's complaints filed against the United States with the World Trade Organization, and the Executive Branch's representations regarding the diplomatic difficulties caused by the state sanctions. See id. at 382-86. 


\section{B. What the Crosby Court Avoided: A History of Distrust}

The Court strenuously declined to discuss the constitutional role that States generally should play in the foreign affairs arena. The decision expressly considered only the preemption argument and, in deciding the issue of preemption, further refused to draw upon "any general consideration of limits on state action affecting foreign affairs." 25 Indeed, the closest the Court came to acknowledging any traditional hesitance about state involvement in foreign affairs was in dismissing the State's argument that Congress's silence militates against preemption, and noting that Congress's "failure to provide for preemption expressly may reflect nothing more than the settled character of implied preemption doctrine that courts will dependably apply." 26 Dispelling any hint that it might thereby have heeded a particular tradition of implied preemption analysis distinct to the realm of foreign affairs, however, the Court continued: "the existence of conflict cognizable under the Supremacy Clause does not depend on express congressional recognition that federal and state law may conflict." 27

By declining to discuss the States' constitutional role in foreign affairs, the Court avoided confronting a consistent theme that emerges from the doctrinal thicket of its prior decisions on federalism in foreign affairs, namely that state participation in foreign affairs can be only harmful to the Nation. As early as 1827, for example, John Marshall, articulated this concern in Brown v. Maryland, ${ }^{28}$ where he noted that state restrictions on foreign commerce and on the importation of goods would inevitably lead to adverse diplomatic consequences for the Nation as a whole. ${ }^{29}$ That the state law in that case was limited in scope, and might have been considered a prudent exercise of state power with few implications for the Nation's interests in foreign affairs, was irrelevant. In Marshall's view, the issue was not whether the State's actions in fact interfered with the national interest or whether the State had exercised good judgment, but the formal question of where the power resided. ${ }^{30}$ For Marshall, it was not sufficient "to say, that [a disastrous] state of things will never be produced; that the good sense of the States is a sufficient security against it." 31 Indeed, Marshall suspected that the States naturally lacked such "good

25. Id. at 381 .

26. Id. at 387 .

27. Id. at 388 .

28. 25 U.S. (12 Wheat.) 419 (1827).

29. See Brown, 25 U.S. (12 Wheat.) at 447 ("What would be the language of a foreign government, which should be informed that its merchants, after importing according to law, were forbidden to sell the merchandise imported? What answer would the U.S. give to the complaints and just reproaches to which such an extraordinary circumstance would expose them? No apology could be received, or even offered. Such a state of things would break up commerce.").

30. See id.

31. Id. 
sense." He expected that a State would "provide judiciously for its own interests," and thus predictably fail to "respect the interests of others." 32 Accordingly, Marshall opted for a formal rule, allocating the power over imports and foreign commerce exclusively to the federal government; otherwise, in his view, the States would act in their own interests and provoke foreign retaliation against the United States as a whole. ${ }^{33}$

The idea that States' involvement in foreign affairs can only redound to the disadvantage of the Nation has run through much of the Court's foreign affairs jurisprudence ever since. A prominent discussion is in Holmes v. Jennison, ${ }^{34}$ in which Chief Justice Taney, writing on behalf of four Justices, expresses a similar mistrust of the States. The case involved Vermont's planned surrender of Holmes to Canadian authorities who sought the extradition to press murder charges. Following Marshall in Brown, Taney presents the issue as one regarding power, not the exercise of good judgment: "[I]f the power [to comply with extradition requests] remains with the states, then every state of the Union must determine for itself the principles on which they will exercise it; and there will be no restriction upon the power, but the discretion and good feeling of each particular state." 35 In Taney's view, that was unacceptable. States could not be trusted to act based on "good feeling" to their sister States or to heed the interests of the Nation as a whole. As the Framers recognized, "any intercourse between a state and a foreign nation was dangerous to the Union" and "open a door of which foreign powers would avail themselves to obtain influence in separate states." 36 Accordingly, the Framers "anxiously desired to cut off all connection or communication between a state and a foreign power." 37 Taney's plurality thus sought to establish the exclusivity

\section{2. $I$ ld. at 440 .}

33. This view of state interests echoes Justice Marshall's decision in McCulloch v. Maryland, 17 U.S. (4 Wheat.) 316 (1819), holding that the States could not be trusted with the power to tax federal instrumentalities, lest nothing would prevent them from destroying the federal bank.

34. 38 U.S. (14 Pet.) 540 (1840).

35. Holmes, 38 U.S. (14 Pet.) at 568. Similarly, Taney expresses particular concern over the fact that a State might in the future extradite a U.S. citizen (which Holmes was not). Taney rejects the notion that the State might act differently, or that the State's obligations might differ, in such a case: "[I]f the surrender of Holmes is not repugnant to the Constitution of the U.S., there is nothing in that instrument that forbids the delivery up of a citizen of any other state, when found within its borders." Id.

36. Id. at 574-75.

37. Id. at 572. Doctrinally, Taney argued that the planned extradition would violate Article I, Section 10's prohibition on entering into agreements with foreign nations absent the consent of Congress. Despite the fact that there did not appear to be any reciprocal agreement between Canada and Vermont, or any unilateral commitment on the part of Vermont, but simply communication regarding the logistics of Holmes's surrender, Taney concluded that an agreement in violation of Article I, section 10, had been reached. To buttress this sweeping conclusion, Taney argued that "the use of all of these terms, 'treaty,' 'agreement,' 'compact,' show that it was the intention of the framers of the Constitution to use the broadest and most comprehensive terms, and that they anxiously desired to cut off 
of federal powers in this area, as opposed to controlling the States' exercise of concurrent powers in light of national interests. ${ }^{38}$

So, too, more modern cases generally deem States' involvement in foreign affairs detrimental to the foreign relations interests of the Nation. In Zschernig v. Miller, ${ }^{39}$ for example, the Court held that state courts' examinations of foreign legal systems in the context of probate proceedings harmed the Nation's foreign affairs. The Court found that these inquiries demonstrated open hostility toward foreign nations and often strayed from the requisite inquiry into whether certain factual predicates for receipt had been met. ${ }^{40}$ The Court there failed to invoke any particular

all connection or communication between a state and a foreign power." $I d$. at 572 . This reflected "one of the main objects of the Constitution," which was "to make us, so far as regarded our foreign relations, one people, and one nation." Id. at 575. Thus, although Taney nominally concluded that this case had involved an "agreement" between Canada and Vermont, the root of the problem was simply that any communication between a foreign nation and a State was suspect, because, ultimately, neither party could be trusted to keep in mind the interests of the Nation as a whole. Nor was the Court in a position to police the parties' proper consideration of these interests. If we are to be "one people, and one nation" with regard to foreign affairs, this unity can, according to Taney, only be achieved by excluding the States from this realm of activity. In this sense, then, Taney's argument goes well beyond the more persuasive prohibition on "bargaining" that Edward Swaine roots in Article I, Section 10. See generally Swaine, Negotiating Federalism, supra note 1.

38. For a similar approach, see Chy Lung v. Freeman, 92 U.S. 275, 280 (1875) (striking down California law requiring bond for arriving alien ship passengers, holding that with exception of state laws "necessary and proper [to protect] against paupers and convicted criminals from abroad," powers to regulate entry of aliens into U.S. "belongs to Congress, and not to the states," just as power to regulate foreign commerce "belongs solely to the national government," and noting generally " $[\mathrm{i}] \mathrm{f}$ it be otherwise, a single State can, at her pleasure, embroil us in disastrous quarrels with other nations").

39. 389 U.S. 429 (1968).

40. Several years earlier, in Clark v. Allen, 331 U.S. 503 (1947), the Court had upheld a state probate rule requiring reciprocity before allowing a nonresident alien to take personal property located within the State by succession or testamentary disposition. The Court held in Clark that the state policy was not properly preempted by a conflicting treaty or federal law, and that the State had not entered into "the forbidden domain of negotiating with a foreign country" or entered into any compact or agreement in violation of Article 10. Id. at 517. Despite the "incidental or indirect effect" of this policy in foreign countries, the Court upheld the provision against constitutional challenge. See id. When the issue came to the Court again in Zschernig, this time from a different State, the Court refused to reconsider its holding in Clark, but reviewed the state court rulings that had been issued since then. The Court found that many state courts were inquiring rather deeply into the domestic legal structures of foreign nations. State courts ostensibly did so in order to determine whether the condition that the nonresident alien would actually receive and retain possession of the inheritance, and the further condition of reciprocity, were met. Trial courts, according to the Supreme Court, had engaged in "minute inquiries concerning the actual administration of foreign law, into the credibility of foreign diplomatic statements, and into speculation whether the fact that some received delivery of funds should "not preclude wonderment as to how many may have been denied "the right to receive." Zschernig, 389 U.S. at 435. 
national policy with which the state courts' actions might conflict, and yet dismissed the federal government's argument that the state activity in question did not "unduly interfer[e] with the U.S.' conduct of foreign relations." 41 As Justice Stewart noted in his concurrence, "[r] esolution of so fundamental a constitutional issue [of whether certain state activity unduly interfered with federal power over foreign affairs] cannot vary from day to day with the shifting winds at the State Department." ${ }^{22}$ Even absent any specific conflict with a treaty or positive act of Congress, the Court held, State forays into foreign policy "may disturb foreign relations." 43 Indeed, whenever state activity "has a direct impact upon foreign relations ... [it] may well adversely affect the power of the central government to deal with those problems." 44 The conclusion in Zschernig was categorical: "[T]he conduct of our foreign affairs is entrusted under the Constitution to the National Government, not to the probate courts of the several States." 45

Similarly, even those decisions that do not categorically exclude the States from the foreign affairs arena, generally focus on the damage done by States to the Nation's foreign policy or foreign commerce concerns. These decisions present the gravamen as being a conflict with positive federal policy, as opposed to dormant federal power. As the Court held in United States $v$. Pink, ${ }^{46}$ state laws and policies must "yield before the exercise of the external powers of the U.S.," otherwise they could thwart the Nation's "foreign policy," leaving "[t] he nation as a whole . . to answer" for difficulties created by a single State. ${ }^{47}$ Again, the vision of state activity as trouble for the Nation prevails. As Justice Frankfurter's concurrence notably stated: "In our dealings with the outside world the U.S. speaks with one voice and acts as one, unembarrassed by the complications as to do-

41. See Zschering, 389 U.S. at 443 (Stewart, J., concurring) (noting Solicitor General's statement).

42. Id.

43. Id. at 441 .

44. Id.

45. Id. As dormant foreign policy analysis, Zschernig was an unusual case, should be viewed as a "judicial reaction to a state's contributions to the Cold War," and has remained "a unique statement and a sole application of constitutional doctrine." See Louis Henkin, Foreicin Affairs and the Constitution 165 (2d ed. 1996). See generally Goldsmith, Federal Courts, supra note 1, at 1643-61; Hans Linde, A New Foreign-Relations Restraint on American Siates: Zschernig v. Miller, 28 ZEITSCHRIFT Für Ausländisches ÖFFentliches ReCH und VólKerrecht 594, 603 (1968); Spiro, Foreign Relations Federalism, supra note 1, at 1242. In its categorical distrust of the states, however, Zschernig echoes older decisions, see supra notes 2940 and accompanying text, as well as more modern ones. See, e.g., Banco Nacional de Cuba v. Sabbatino, 376 U.S. 398 (1964) (invoking application of "act of state" doctrine and asserting federal jurisdiction over customary international law). Professor Spiro attributes this 1964 decision, in which the Court insisted on strong control over the foreign policy activities of the states for fear of retribution imposed on the Nation as a whole, on Cold War politics as well. See Spiro, Foreign Relations Federalism, supra note 1 , at 1244-45.

46. 315 U.S. 203 (1942).

47. Pink, 315 U.S. at 232. 
mestic issues which are inherent in the distribution of political power between the national government and the individual states." 48 On this view, then, States merely add "complications" that have no place in the foreign affairs arena. ${ }^{49}$

More recent decisions can be read to echo the idea that pluralism in foreign affairs is simply an evil that it is best to contain. Thus in Japan Line Ltd. v. County of Los Angeles, ${ }^{50}$ the Court struck down California's ad valorem property tax on foreign shipping containers, because it impaired federal "uniformity" and the ability of the federal government to "speak [ ] with one voice." ${ }^{1}$ Sounding the theme of state involvement in foreign affairs as detrimental to the Nation, the Court noted that a state tax on foreign commerce could give rise to "international disputes" and "foreign . . . retaliation ... directed at American transportation equipment in general, not just that of the taxing State, so that the Nation as a whole would suffer." 52

Finally, even the Court's more moderate doctrine of positive federal foreign affairs preemption was, prior to Crosby, based on a jaundiced view of state participation in foreign affairs. The Court's most prominent preemption case in the foreign affairs arena, Hines v. Davidowitz, ${ }^{53}$ for example, refused to consider the question of dormant exclusivity, ${ }^{54}$ but nonetheless applied a presumption against state involvement in foreign affairs. It, too, voices the idea that States' involvement in foreign affairs is dangerous to the Nation. The Court struck down Pennsylvania's Alien Registration Act after inquiring generally whether the state law "stands as an obstacle to the accomplishment and execution of the full purposes and objectives of Congress." 55 Pennsylvania's scheme differed in some ways from the subsequently enacted federal Alien Registration Act, but those

48. Id. at 242.

49. As Justice Sutherland famously put it in United States v. Belmont: "In respect of all international negotiations and compacts, and in respect of our foreign relations generally, state lines disappear. As to such purposes, the state of New York does not exist." Justice Sutherland's view was reminiscent of his opinion for the Court in United States \%. Curtiss-Wright Export Corp., 299 U.S. 304 (1936), in which he set forth his general argument for the transfer of foreign relations power from the Crown to the Union of the Articles of Confederation and then to the federal government under the Constitution. That theory, which "did not depend on the affirmative grants of the Constitution," $i d$. at 318 , has suffered widespread academic criticism. Cf. HenkIN, supra note 45, at 19-20 (citing critics of Curtiss-Wright).

50. 441 U.S. 434 (1979).

51. Japan Line, 441 U.S. at 456.

52. Id. at 450-51 (citations and footnotes omitted); cf. Container Corp. of Am. v. Franchise Tax Bd., 463 U.S. 159 (1983) (quoting and applying Japan Line, but upholding unitary business rule for state corporate franchise tax).

53. 312 U.S. 52 (1941).

54. See Hines, 312 U.S. at 63 (refraining from reaching "the argument that the federal power in this field, whether exercised or unexercised, is exclusive").

55. Id. at 67. Although formally this is classified as "obstacle preemption," see, e.g., Goldsmith, Statutory Foreign Affairs Preemption, supra note 1, at 202, it may in this instance also be recognized as a form of "field preemption." 
differences ultimately were not dispositive. Instead, the Court explained more generally that where Congress:

in the exercise of its superior authority in this field, has enacted a complete scheme of regulation and has therein provided a standard for the registration of aliens, states cannot, inconsistently with the purpose of Congress, conflict or interfere with, curtail or complement, the federal law, or enforce additional or auxiliary regulations. ${ }^{56}$

The Court's judgment regarding preemption was strongly influenced by a general recognition of the national interest in conducting foreign policy and concomitant fears about allowing States to regulate in the area. The Court specifically emphasized the delicacy surrounding the treatment of aliens, adding: "it is of importance that this legislation is in a field which affects international relations, the one aspect of our government that from the first has been most generally conceded imperatively to demand broad national authority." 57 In other words, regardless of whether in a different context an act such as this one would have preempted the field, ${ }^{58}$ in the foreign affairs context such an act did. ${ }^{59}$ In that context, the federal government alone represents "the collective interest of the . . states." 60 Accordingly, both local and national interests demand that the federal government's authority in foreign affairs "be left entirely free from local interference." 61 In light of this strong predisposition against state "interference" matters affecting the Nation's foreign relations, the Court unsurprisingly had little difficulty concluding that Congress sought to establish "a single integrated and all-embracing" aliens registration system that was intended to preclude the States from adding auxiliary registration requirements on law-abiding aliens within their jurisdiction. ${ }^{62}$

Among the various strands of foreign affairs jurisprudence set forth above, Hines's preemption doctrine figures most prominently in Crosby. Crosby both decides the case on preemption grounds and cites Hines's "obstacle" test as guiding the inquiry. Yet from reading the Court's opinion in Crosby, we would not know that Hines strongly emphasized the foreign affairs context of its preemption inquiry. Indeed, Crosby studiously avoids citing or quoting any portion of Hines that discusses general considerations of the federal/state balance in foreign affairs. And Crosby refrains

56. Hines, 312 U.S. at 66.

57. Id. at 68 .

58. See, e.g., Goldsmith, Statutory Foreign Affairs Preemption, supra note 1, at 202.

59. As Professor Tribe noted in comparing different instances of the Court's determination in favor of field preemption, in Hines "the Court was extremely solicitous of the paramount federal interest in matters germane to foreign affairs." Laurence H. Tribe, 1 american Constitutional law 1210 (3d ed., 2000).

60. Hines, 312 U.S. at 63.

61. Id.

62. Id. at 74 . 
from quoting the Hines proviso about the specific foreign affairs context in which federal power is broad and state power is at a minimum. Instead, Crosby simply quotes Hines's general "obstacle" formula and approaches the question as one of preemption without presumption. ${ }^{63}$ In doing do, Crosby avoids the general theme of prior cases that States can do only harm to the Nation when they become involved in foreign relations.

In sum, the Supreme Court's jurisprudence on federalism in foreign affairs has consistently focused on the detriment of state activity in this area to the Nation as a whole. Crosby is a departure from that tradition in that it refrains from making any general observations on the relation between the States and the federal government in this arena. As the next section will show, such restraint may be wise, as not all state involvement in foreign affairs is detrimental to the foreign affairs interests of the Nation. Indeed, as the following section's review of state participation in foreign affairs indicates, state activity may benefit the Nation as well.

\section{State and Local Participation in the Foreign Affairs Arena}

State and local activities in the foreign affairs arena, while not a new phenomenon, ${ }^{64}$ have expanded over the past thirty years. As the sphere of international activity has grown beyond issues of security and state recognition to reach many economic, social, cultural, and environmental issues previously regulated at the national or subnational level of government, subnational governments within federal systems worldwide have taken an increased interest in the conduct of foreign affairs. ${ }^{65}$ The

63. See Crosby v. Nat'l Foreign Trade Council, 530 U.S. 363, 373 (2000) (quoting Hines, 312 U.S. at 67); see also id. at $374 \mathrm{n} .8$ (expressly rejecting application of any preemption presumption.

64. For a useful discussion of the history of state involvement in the making and pursuit of U.S. foreign policy, see Dennis James Palumbo, The States and American Foreign Relations 290 (1960) (unpublished Ph.D. dissertation, University of Chicago) (on file with author) (reviewing episodes of States' involvement in foreign affairs dating back to early nineteenth century and concluding that "States participate in foreign relations in many areas," and noting that "States have had extensive influence in foreign relations in regard to economic issues, border issues, minority groups, treaty negotiations, cultural exchanges, and national defense").

65. See generally Federalism and International Relations-The Role of Subnational Units (Hans J. Michelmann \& Panayotis Soldatos eds., 1990); Foreign Relations and Federal Systems (Brian Hocking ed., 1993); Brian Hocking, Localizing Foreign Policy (1993) [hereinafter Hocking, Localizing Foreign Policy]; Robert O. Keohane \& Joseph S. Nye, Power and Interdependence: World Politics in Transition (1977); Foreign Policy in Federal States, 61 InT'L J. 3 (Robert O. Matthews \& Charles Pentland eds., 1986); Robert D. Putnam, Diplomacy and Domestic Politics: The Logic of Two-Level Games, 42 INT'L ORG. 459 (1988). This is not to say that international law has never reached deeply into domestic matters. See Golove, Treaty Making, supra note 1, at 1104-16 (discussing regulation of aliens' rights to dispose of their property under bilateral treaties). Yet many issues previously thought of as exclusively domestic matters, such as a State's treatment of its own citizens, have in the past century become a principal target of international 
States within the U.S. federal system are no exception. ${ }^{66}$ States have vigorously promoted trade and investment opportunities, and also engaged in international initiatives for more "political" purposes, such as effecting change in conditions or policies within foreign nations. ${ }^{67}$ Although many of these activities, taken individually, may be considered marginal or even obscure, taken together they amount to a pervasive subnational force in the conduct of the Nation's foreign affairs.

Apart from demonstrating the immense level of state activity in this arena, this part argues that although tensions between federal and state policies do emerge periodically, state activities often benefit the Nation. State officials are frequently in a better position to promote trade and investment opportunities at home. Relative to federal actors, state officials may enjoy an informational advantage relevant to crafting or carrying out international agreements. State officials may assist national policymakers by providing broad political support that differs from the support garnered by organized economic interests. And independent state action may induce federal officials to take up international issues that would otherwise not make it onto their policy agenda. Indeed, the federal government has frequently embraced the state and local concerns as its own and, especially in the area of trade and investment, has regularly included state and local governmental representatives in the formulation of federal foreign policy itself.

\section{A. Trade and Investment}

Prior to 1970, States and local governments rarely engaged in international economic activities. ${ }^{68}$ In the early 1970 s, however, the slowdown in the domestic economy led to a general search for alternative means of economic expansion, and state officials set their gaze abroad. ${ }^{69}$ As a result, state activity has burgeoned in this sector, and international economic development has since become perhaps the most significant area of state foreign policy activity. ${ }^{70}$ As Bayless Manning noted, the deep global

law. See generally Bradley \& Goldsmith, supra note 1 . But see Koh, supra note 1 (responding to Bradley \& Goldsmith).

66. See, e.g., John M. Kline, State Government Influence in U.S. International Economic Polico 2, 23-24, 35-36 (1983) [hereinafter Kline, State GoverNMENT] (explaining that States now view foreign policy issues as highly relevant).

67. For a brief discussion of potential reasons for subnational foreign policy involvement in such "political" issues, see Hans J. Michelmann, Conclusion, FEDERalism ANd International. Relations-The Role of Subnational Units, supra note 65, at 299-306; Hocking, Locializing. Foreign Policr, supra note 65, at 18-24.

68. See Earl H. Fry, The Expanding Role of State and Local Governments in Foreign Affairs 67 (1998). Although there was some level of state and local activity, the prevailing idea was that centralization would inevitably proceed. See id.

69. See, e.g., Kuine, State Government, supra note 66, at 53-55.

70. Ivo Duchacek traces the development back to the 1960s. See Ivo D. Duchacek, Perforated Sovereignties: Towards a Typology of New Actors in International Relations, in Federalism and International Relations-The Role of SubnaTIONAL UNITS, supra note 65 , at 1,5. John Kline suggests that the involvement of 
interdependence in the economic arena has fostered this activity by blurring the distinction between domestic and international matters:

The economic interdependence of the modern world is more than international. It is also inter-local. ... . [A] lmost every region and every economic group is on some way in the export or import business or, usually, both. As a result, every jiggle in the pattern of the international economy is likely to pinch some local group ... . . ${ }^{71}$

Although some state activity has been an isolationist reaction to this interdependence, ${ }^{72}$ much has entailed reaching out and engaging vigorously with foreign nations and their subnational units of government.

For example, almost every State has sent trade delegations abroad, ${ }^{73}$ and several have individual offices that coordinate comprehensive policy on international affairs for the State. ${ }^{74}$ State officials often bargain with

the states in foreign affairs is due to the "increased global economic interdependence effects that reached U.S. shores relatively late due to the country's aberrant economic dominance in the immediate aftermath of World War II destruction." KLine, STATE Governments, supra note 66 , at 2 . For the view that global interdependence was extensive nearly one hundred years earlier, but had been systematically suppressed in the wake of World War I, see Paul Krugman, Pop INTERNATIONALISM 205-14 (1996). For an account of the impact of global economic interdependence on the structure of business and industry, see generally Federal Trade Comm'n, Anticipating The 21st Century: Competionon Policy in the New High-Tech Global Marketplace, reprinted in 70 Antitrust \& Trade Reg. Rep. (BNA) No. 1765 (Special Supp.) (June 6, 1996).

71. Bayless Manning, The Congress, the Executive, and the Intermestic Affairs: Three Proposals, 55 Foreicn AfF. 306, 309 (1977).

72. See James D. Southwick, Binding the States: A Survey of State Law Confornance with the Standards of the GATT Procurement Code, 13 U. PA. J. INT'L BuS. L. 57, 73-76 (1992) (reviewing States' "buy American" and "buy in-State" legislation); see also Kline, State Government, supra note 66, at 87-107 (describing "buy American" movement and similar state and local measures to limit foreign business and investment activities in United States). The federal government maintains a similar policy. See 41 U.S.C. $\$ \$ 10 a-10 d(2000)$. For a discussion of these policies in the context of the General Agreement on Tariffs and Trade (GATT), see JOHN H. Jackson, The World Trading System: Law and Policy of International EcoNOMIC RElations 224-28 (2d ed. 1997).

73. See Richard B. Bilder, The Role of States and Cities in Foreign Relations, 83 AM. J. INT'L L. 821, 822 (1989). In 1993 alone, twenty-seven states led a total of eightythree trade and investment missions to foreign countries. See FrY, supra note 68, at 69. By 1994, thirty-nine states and Puerto Rico maintained a total of 162 foreign offices all over the world. See id. at 68-69. Today, States maintain a total of nearly 260 overseas offices and representatives to advance their interests abroad. See International Trade Administration, National Export Directory, at hltp:// www.ita.doc.gov/TICFrameset.html (see "Trade Offices Nationwide" and "NED by State") (last visited Mar. 31, 2001); see also National Association of State Information Resource Executives Representing Chief Information Officers of the States, Economic Development and Commerce, at http://www.nasire.org/ stateSearch/displayCategory.cfm?Category=Economic (last visited Mar. 3, 2001).

74. See generally Eduardo E. Neret \& Marcio W. Valladares, The Florida International Affairs Act: A Model for State Activism in Foreign Affairs, 1 J. Trans. L. \& Pol.'Y 197 (1992). California is particularly active in this regard, with its five state agen- 
foreign investors and exercise state regulatory powers to attract business to the region. ${ }^{75}$ And States cooperate with one another, as in the creation of the National Association of State Development Agencies (NASDA), which has coordinated trade and investment missions to cities abroad, ${ }^{76}$ and the Council of American States in Europe, which coordinates the activities of U.S. States with offices in Western Europe. ${ }^{77}$

Subnational cooperation in trade and investment matters includes coordination not only among U.S. States, but with foreign officials as well. Direct action to attract investment, for example, may involve high level, quasi-diplomatic exchanges, as in the case of California's recent agreement with Israel to create a California-Middle East Economic Task Force in support of economic development opportunities between California and the Middle East region. ${ }^{78}$ States have also established regional councils and organizations whose membership extends beyond domestic borders, such as the Pacific Northwest Economic Region, which encourages regional economic development, ${ }^{79}$ or the Three Californias Commission, which coordinates contacts between California and the two Mexican Baja Californias. ${ }^{80}$ Governors, apart from leading trade and investment missions overseas, have similarly established transnational regional organizations. $^{81}$ In addition, state officials specifically engage with their foreign

cies devoted to foreign trade issues, and twelve foreign offices. See California Technology, Trade and Commerce Agency, Finding Markets, at http:// commerce.ca.gov/international/it_home.html (last visited Feb. 17, 2001).

75. Shrewd companies can, however, play state officials off against one another in an effort to cut the best deal. See Kevin Phillips, Arrogant Capital: Washington, Wall Street, and the frustration of American Politics 72 (1994). See generally Reuven S. Avi-Yonah, Globalization, Tax Competition, and the Fiscal Crisis of the Welfare State, 113 Harv. L. Rev. 1573 (2000); Andrew L. Kolesar, Note, Can State and Local Tax Incentives and Other Contributions Stimulate Economic Development?, 44 TaX LaW. 285 (1990).

76. See Kline, State Government, supra note 66 , at $42-43$.

77. FRY, supra note 68 , at 75 .

78. See California Technology, Trade and Commerce Agency, Finding Markets, at http://commerce.ca.gov/international/it_home.html (last visited Feb. 17, 2001); California Technology, Trade and Commerce Agency, Califormia Creates Mid-East Economic Cooperation Task Force: Pact Will Support Regional Economic Development, at http://commerce.ca.gov/latest/press/2000/pr947635921.html (last visited Feb. 17, 2001).

79. See Fry, supra note 68 , at 73.

80. Ivo C. Duchacek, The International Dimension of Subnational Self-Government, 14 Publius 5, 10 (1984) [hereinafter Duchacek, International Dimension]. Similar border state arrangements exist in Arizona and New Mexico. See id.

81. See John Kincaid, American Governors in International Affairs, 14 Publius 95, 107 (1984) (discussing mid-America International Agri Trade Council, Southeast U.S.-Japan Association and Western Governors' International Market Development Project); FrY, supra note 68, at 73 (discussing organization of Northeast Governors and Eastern Canadian Premiers (NEGCEP)). 
counterparts to attract business not only to the U.S. but to neighboring foreign regions as well. ${ }^{82}$

Although such activity may lead to costly competition among the States, ${ }^{83}$ direct state involvement may also redound to the benefit of the United States by, for example, effectively attracting foreign investment, which States are often in the best position to do. Thus, state governors, for example, have emerged as the chief economic ombudsman to promote local industry as well as trade and investment opportunities abroad. ${ }^{84}$ Governors provide foreign investors-be they governmental or private-with a single contact for help and guidance in dealing with domestic regulation and business practices. In the words of one observer: "The presence of the governor in establishing foreign economic relations adds an air of assurance that the state will serve as a trustworthy partner, and that foreign investors will not be left to fend entirely for themselves in the wilds of the American economy." 85 U.S. cities have similarly engaged in economic development activities through the U.S. Conference of Mayors. $^{86}$ And taking up the role of chief spokesperson for the economic development of their locale, several big city mayors have led large trade and investment missions abroad, ${ }^{87}$ and even smaller cities, such as Denver and Duluth, have followed suit. ${ }^{88}$ Indeed, the federal government itself has acknowledged the ability of state and local officials effectively to promote U.S. investment opportunities abroad, especially when communicating

82. For example, California's trade and commerce secretary accompanied a Mexican delegation to South Korea to help convince Daewoo to establish a $\$ 270$ million television picture tube plant across the border in Baja California Norte. See FRY, supra note 68 , at 74 .

83. See generally Howard N. Fenton, III, The Fallacy of Federalism in Foreign Affairs: State and Local Foreign Policy Trade Restrictions, 13 Nw. J. INT. L. \& Bus. 563 (1993).

84. See Kincaid, supra note 81 , at 105-06, 110.

85. Id. at 106.

86. See Duchacek, International Dimension, supra note 80 , at 5 . The U.S. Conference of Mayors, for example, coordinated an event in Zürich, in which representatives from 180 U.S. cities, port authorities and state or local development or trade agencies vied for Swiss business. Id. at 6 .

87. For example, San Francisco Mayor Willie Brown led a successful seventymember delegation to France in November, 1996, see FRY, supra note 68, at 84-85, and New York City led similar missions to Britain, France and Germany in 1992, see James C. McKinley, Jr., Dinkins Returning from Europe, Hoping Investment Will Follow, N.Y. Times, June 6, 1992, at $\$ 1-25$; James C. McKinley Jr., Dinkins Heads for Europe as City's Salesman, N.Y. TIMEs, May 20, 1992, at \$ 1-21. A decade earlier, New York City had already led missions to England and West Germany, see Robin Herman \& Laurie Johnston, New York Day by Day, N.Y. Times, Feb. 16, 1983, at B-5, as well as to China and Japan, see Robert McG. Thomas Jr., Koch, Gift-Laden, Departs for China, N.Y. Times, Feb. 23, 1980, at §1-23.

88. See, e.g., James Brooke, Goodbye, Cowtown; Denver Enters the World Arena, N.Y. Times, Jul. 20, 1999, at A10 (noting that Denver Mayor Webb led delegation of eleven other American mayors on ten-day trip to Senegal, Ghana); William H. Honan, Sister Cities Of World Unite; Duluth Finds a Key to the Global Economy, and Cultural Ties, Too, N.Y. Times, Jul. 8, 2000, at Gl (discussing non-profit city-to-city network). 
with foreign entities considering direct investments in the U.S. economy. ${ }^{89}$

\section{B. Political Activity}

State and local governments have also engaged in foreign policy initiatives with more "political" goals in mind, that is, to promote policies unrelated to their own economic development. ${ }^{90}$ Sometimes these "political" activities are difficult to distinguish from the more basic economic and cultural engagement of which they are a part. At other times, the principal purpose of the action is clearly the "political" goal itself. Here, too, we see prominent instances, particularly of collective state and local action, in which such engagement may be considered useful for the $\mathrm{Na}$ tion as a whole.

Cities, Counties, and States, for example, have forged formalized ties across national boundaries, which promote business, professional, cultural, and educational exchanges as well as advancing political engagement more generally. Currently, 1300 U.S. communities have established formal links with 2400 of their counterparts in 137 nations, and all fifty States, as well as American Samoa, Guam, Puerto Rico and Washington, D.C., have formed a total of 201 relationships with subnational units of government in approximately fifty foreign nations. ${ }^{91}$ In some instances, these relationships preceded formal diplomatic ties at the national level, as in the case of Cuba, where at least six U.S. cities have sister city relationships with Cuban counterparts. ${ }^{92}$ In others, sister city relationships were used to bring into focus human rights and social justice issues otherwise neglected by the federal government. ${ }^{93}$ Local officials have used visits to

89. See Kline, State Government, supra note 66 , at 72 (citing U.S. General Accounting Office, Foreign Direct Investment in the United States-The Federal Role, Report to the Congress by the Comptrolleer General of the United STates ii (1980)). In part, this attitude is a reaction to the fact that the "State Department advises its Embassies that promotional activities disrupt market forces ...." Id. The States as market actors can act self-interestedly in a manner that federal agencies cannot. Id.

90. See generally Fenton, supra note 83.

91. Telephone interview with Cynthia Maka, Regional Director for Asia and Oceania, Sister Cities International (Feb. 28, 2001). See generally http://www.sistercities.org.

92. The relationships are: Mobile (AL)-Habana; Madison (WI)-Camaguey; Pittsburgh (PA)-Matanzas; Bloomington (IN)-Santa Clara; Richmond (CA)-Regla; and Oakland (CA)-Santiago. Three more have been agreed upon, but not yet executed: Takoma (WA)-Cienfuegos; Milwaukee (WI)-Neuvitas; and Philadelphia (PA)-Cardenas. Several more are in progress. Telephone interview with Lisa Valanti, President of U.S. Cuba Sister Cities Association (Feb. 28, 2001). See generally http://www.USCSCA.org.

93. See, e.g., John M. Kline, Managing Intergovernmental Tensions: Shaping a Stale and Local Role in U.S. Foreign Relations, in FOREIGN RELATIONS AND FEDERAL STATES, supra note 65, at 105, 113 [hereinafter Kline, Intergovernmental Tensions] (noting sister city programs with "black townships in South Africa, small rural communities on the edge of conflict areas in El Salvador and Nicaragua, Palestinian 
highlight political issues, ${ }^{94}$ and even trade missions have taken on significant political content, as when Idaho sponsored missions to Libya in the 1970s and hosted Libyan missions in the United States. ${ }^{95}$ Trade, development and politics are similarly intertwined when the U.S. Conference of Mayors pursues the creation of an international alliance with counterparts throughout the world, engages Chinese mayors in the form of a cooperative agreement and promotes cooperation in the Middle East. ${ }^{96}$

Beyond such hybrid activities, many cities and counties have formally expressed their views on a host of foreign policy matters, including the Vietnam War, the Comprehensive Test Ban Treaty, the status of Taiwan and nuclear disarmament. ${ }^{97}$ Others have gone further and limited their investments, much in the way Massachusetts did with its procurement regulations, in order to further political objectives. ${ }^{98}$ Yet other state and local officials have obstructed the movement of foreign officials in the United States based on foreign policy considerations. ${ }^{99}$

towns in the Israeli-occupied West Bank, cities in the former Soviet Union . . . and communities in China").

94. See James C. McKinley, Jr., Angry Dinkins Defends Travel to South Africa, N.Y. Times, Oct. 12, 1991, at $\$ 1-33$.

95. See Fry, supra note 68 , at 92 . Libya sought, by various means, including retaining the services of Billy Carter as a lobbyist, to obtain replacement parts for its stock of American-built aircraft and to purchase new commercial planes from the U.S. See P. Edward Haley, Qaddafi and the United States Since 1969 147-54 (1984). In part, the Libyan-Idaho contacts were an effort to influence Senator Frank Church, then Chair of the Foreign Relations Committee. See William Safire, Libya and Idaho, N.Y. Times, Feb. 5, 1979, at A27.

96. See U.S. Conference of Mayors, International Affairs, U.S. MAYOR NEwSPAPER (2000), available at http://www.usmayors.org/uscm/us_mayor_newspaper/ documents/06_26_00/international_article.html (last visited Sept. 2, 2001); U.S. Conference of Mayors, Press Release, Conference President Coles to Lead U.S. Delegation to International Mayors Conference in Jerusalem (Mar. 15, 2001), al http:// www.usmayors.org/uscm/news/press_releases/documents/israel031501.asp (last visited Sept. 2, 2001).

97. FRY, supra note 68 , at 92 (stating that seven cities held referenda on Vietnam War; three measures opposing war succeeded; over 200 local governments passed resolutions expressing support for Comprehensive Nuclear Test Ban Treaty); id. at 96 (noting legislative resolutions and gubernatorial trips to Taiwan); Michael H. Shuman, Dateline Main Street: Local Foreign Policies, 65 ForeigN Pol'y 154 (1986-87) ("More than 900 local governments . . . passed a nuclear freeze resolution and helped pressure President Ronald Reagan to launch the Strategic Arms Reductions Talks in Geneva.").

98. Seventeen States and forty municipalities have expressed their views on Northern Ireland, endorsing the "MacBride principles," which seek to eliminate discrimination against Catholics and accordingly limit pension fund and other investments in companies violating these principles. See John M. Kline, Continuing Controversies Over State and Local Foreign Policy Sanctions in the U.S., 29 Publius 111, 116 (1999) [hereinafter Kline, Continuing Controversies]; see also FRY, supra note 68, at 95; Fenton, supra note 83, at 569; Kevin Whitelaw, The Very Long Arm of the Law: Is the World Ready for 7,284 Secretaries of States?, U.S. News \& WORLD ReP., Oct. 14, 1996, at 57 (discussing selective purchasing laws).

99. In 1983, after a Soviet aircraft downed the Korean Airlines passenger jet, the governors of New York and New Jersey imposed a temporary embargo on So- 
More significantly, state and local governments have in recent history intervened collectively in several foreign policy issues that ultimately became issues of national importance. In these instances, the States dramatically imposed economic and regulatory pressures to make their voices heard at national and international levels. And while federal officials have criticized these actions along the way, the federal government ultimately took up these concerns and in some cases embraced subnational government views in resolving the underlying issue.

In the 1970s, for example, the federal government had considered, but initially failed, to take action in response to the Arab League's boycott of Israel. The boycott was extensive. Members of the Arab League refused to engage in direct economic relations with Israel, to deal with corporations doing significant business with Israel and to purchase any goods with components made by boycotted firms. Despite the lack of political support at the national level, local pressure sufficed to move thirteen States to pass their own anti-boycott measures. ${ }^{100}$ Several States, including New York, New Jersey, Illinois, California, Ohio, Massachusetts and Maryland, enacted legislation that provided for penalties, including fines and imprisonment for U.S. residents, for compliance with the terms of the boycott. $^{101}$ Others used their antitrust laws, or threatened their use, against complying individuals and firms. ${ }^{102}$ While these actions were not without international effect, their primary purpose was to force a nationwide dialogue on this issue in the United States and to move the federal government to take action, which the sponsors of the state measures considered overdue. ${ }^{103}$ And indeed, due in part to the diversity of state legislation, which apparently created difficulties both for business and diplomats, support for comprehensive federal action ultimately coalesced. Soon after many of the state provisions were in place, the Congress passed the Export Administration Act, preempting state laws and staking out a comprehensive national position against the boycott. ${ }^{104}$

viet spirits, see FRY, supra note 68, at 92, and refused to allow Soviet Foreign Minister Andrei Gromyko to land at their local airports, see Kincaid, supra note 81, at 96. Instead of attempting to preempt these policies, President Reagan allowed Gromyko to land at a nearby federal airbase, but Gromyko cancelled his planned trip to the United Nations. Id. New York City recently welcomed Gerry Adams, the Sinn Fein leader, to City Hall, and evicted Yasser Arafat from a New York Philharmonic concert. See Fry, supra note 68 , at 98 .

100. See generally $\mathrm{FrY}_{\mathrm{R}}$ supra note 68 .

101. See Kline, State Government; supra note 66, at 187-94.

102. See id. at 189.

103. See, e.g., id. at 192 (quoting Maryland's Attorney General Francis B. Burch making case for federal preemption in testimony before U.S. House of Representatives).

104. See Kline, Continuing Controversies, supra note 98, at 155; Export Administration Act of 1979, Pub. L. No. 96-72, 93 Stat. 503. The Act prohibited any cooperation with the Arab boycott of Israel by categorically forbidding U.S. citizens from refusing to do business with states boycotted by a third country and from engaging in employment discrimination or providing the kind of information the 
The States again prominently flexed their foreign policy muscle in the 1980 s to protest South Africa's apartheid policy. ${ }^{105}$ Since the early 1970s, students, religious organizations, civil rights groups, human rights groups and labor unions had engaged in a grass roots lobbying effort of state and local governments. ${ }^{106}$ As a general matter, the lobbying effort was not deeply coordinated, but rather the result of numerous disparate organizations networking in their search for effective local means of putting pressure on the South African government. ${ }^{107}$ Here, too, local activity was in some tension with the "constructive engagement" approach taken by national officials at the time. ${ }^{108}$ Yet state and local activity may have raised awareness of the issue to the point of demanding a more specific federal response. After twenty-eight States, as well as 130 cities and counties, enacted sanctions against enterprises doing business with South Africa, the federal government finally took action, passing the Comprehensive Anti-Apartheid Act of 1986. ${ }^{109}$

Arab boycott office in Damascus used to promote the boycott. It did, however, permit firms to obey local laws when operating in foreign jurisdictions. For a broader history of the Arab boycott and efforts in the U.S. to counteract it, see generally Aaron J. Sarna, Boycott and Blacklist: A History of Arab Economic WARFARE AGAINST ISRAEL (1986).

105. See generally Janice Love, The U.S. AnTi-Apartheid Movement: Local Activism in Global Politics (1985); Kevin P. Lewis, Dealing with South Africa: The Constitutionality of State and Local Divestment Legislation, 61 TUL.. L. Rev. 469 (1987); Peter J. Spiro, Note, State and Local Anti-South Africa Action as an Intrusion Upon the Federal Power in Foreign Affairs, 72 VA. L. Rev. 813 (1986).

106. See Love, supra note 105, at 29-31. On local activism of international dimensions more generally, see Hocking, Localizing Foreign Policy, supra note 65, at 15-18, and Michael Clough, Grass-Roots Policymaking; 73 Foreign Aff. 2 (1994).

107. See Love, supra note 105 , at 50-51.

108. See, e.g., Kline, Intergovernmental Tensions, supra note 93, at 111; Spiro, Foreign Relations Federalism, supra note 1, at 827-31. See generally Chester Crocker, An Update of Constructive Engagement in South Africa, 85 DeP'T StaTe Bull. 2094 (1985) (providing testimony of Assistant Secretary of State for African Affairs before Senate Subcommittee on African Affairs).

109. See Comprehensive Anti-Apartheid Act of 1986, Pub. L. 99-440, 100 Stat. 1086 (codified at 22 U.S.C. $\$ 500$ et seq.). See FrY, supra note 68, at 5; see also Lewis, supra note 105, at 471-472 (noting that at least nineteen States and sixty-two cities and counties had passed divestment measures). During the mid-1980s, state and local sanctions found support in a Democratic Congress that opposed the "constructive engagement" policy of the Reagan Administration. See Garrett M. Smith, Note, Board of Trustees v. City of Baltimore: Public Pension Fund Divestment of South African Securities Upheld, 49 MD. L. Rev. 1030, 1047 (1990). In Board of Trustees $v$. Mayor $\mathcal{E}$ City Council of Baltimore, 562 A.2d 720 (Md. 1989), cert. denied sub nom. Lubman v. Mayor \& City Council of Baltimore, 493 U.S. 1093 (1990), the court found no congressional intent to preempt subnational sanctions against South Africa; indeed, it found that Congress had by negative implication failed to preempt state legislation. See id. (addressing negative implication argument and citing H.R. 549, which was passed contemporaneous with Anti-Apartheid Act of 1986 and which expressly declared that it was House's intent not to preempt other sanctions); see also David M. Billings, Decision: Foreign Affairs Powers-PreemptionApartheid-State and Local Divestiture Laws, 84 Am. J. INT'L. L. 568 (1990). 
More recently, subnational foreign policy pressure contributed to obtaining a settlement of claims arising out of German and Swiss government and corporate conduct during the Nazi era. ${ }^{10}$ State and local government officials intervened prominently to put pressure on Swiss banks still holding assets of Holocaust victims to settle the accounts with the victims' heirs. A coalition of 900 state and local officials threatened to impose sanctions in the form of selective investment policies ${ }^{111}$ and regulatory restraints. ${ }^{12}$ Although the U.S. State Department originally opposed such actions, ${ }^{113}$ it was not opposed to a settlement of the claims. The federal government chose not to preempt the state action, but instead took up the issue and mediated the negotiations between the parties. State and local pressures continued to be the moving force throughout the negotiations. According to the Washington Post, the threat of state and local sanctions was "a major factor in inducing the banks to settle," 114 and the Financial Times reported that "every important breakthrough in the negotiations came soon after threats from US local government officials to impose sanctions." 115 Swiss banks offered a settlement only shortly before the New York Banking Department was to decide on the approval of the merger of the New York branches of UBS and SBC to form the world's third largest bank. ${ }^{116}$ The state Banking Department, which had previously cited Swiss inaction on this issue as a source of concern, now approved the merger, referring to the "sea change" in attitude regarding the wartime accounts. ${ }^{117}$ State officials across the United States soon followed suit and withdrew their threat of sanctions. ${ }^{118}$

State and local officials similarly put pressure on German government and industry to settle Holocaust claims. New York's Banking Board again threatened to block a merger, this time of Deutsche Bank with Bankers 29.

110. See generally Kline, Continuing Controversies, supra note 98, at 121-23, 126-

111. State and local governments, for example, threatened to withdraw pension funds from accounts connected with the targeted banks. See Joan Warner \& John Parry, Swiss Banks: The Noose Tightens, Bus. WK., Jul. 27, 1998, at 66.

112. State officials, for example, raised objections in the approval process of the merger between the Union Bank of Switzerland and Swiss Bank Corporation. See Reject Bank Merger, New York Tells Fed, N.Y. Times, Mar. 25, 1998, at B1.

113. See David Cay Johnston, New York Officials to Impose Sanctions on Siviss Banks Sept. 1, N.Y. Times, Jul. 3, 1998, at A3 (quoting State Department position that sanctions were "unjustified, unwarranted and counterproductive").

114. John M. Goshko, Swiss Banks' Pact Ends N.Y. Threat of Sanctions; Holocaust Victims' Heirs Due Restitution, WAsH. Post, Aug. 14, 1998, at A14.

115. John Authers \& Richard Wolfe, When Sanctions Work, Fin. Times (London), Sept. 9, 1998, at 22.

116. See David E. Sanger, Swiss Banks Said to Offer Holocaust Payment, N.Y. Times, Jun. 5, 1998, at A9 (discussing settlement offer negotiations and merger approval).

117. See id.

118. See John Authers \& William Hall, Holocaust Deal Ends Sanctions Threat, Fin. Times (London), Aug. 14, 1998, at 2; Amy Waldman, Holocaust Accord Ends Plan for Sanctions, N.Y. Times, Aug. 14, 1998, at A8. 
Trust, unless a satisfactory settlement regarding the German bank's activities during the Nazi-era was reached. ${ }^{119}$ As in the case of the Swiss banks, the federal government became involved in the negotiations and helped mediate the process. Thus, rather than simply preempting local activism as threatening to the Nation, federal policymakers came to recognize the issue as one of legitimate national concern. Although counterfactuals are very difficult to prove, it is quite likely that the federal government would not have embraced this issue as vigorously as it did if state activity had not placed the question squarely on the federal government's agenda. As with the Swiss banks case, federal negotiators took up the local officials' concern, and ultimately helped bring about a positive settlement of the issue. $^{120}$

A third recent episode relates to the European insurance industry and the unpaid claims and expunged policies of Holocaust victims. Here, again, local regulators brought their influence to bear in the international scene, with regulators in California leading the charge. State insurance regulators threatened to withhold regulatory certification and blocked local mergers based on the European insurers' failure to cooperate in the settlement of claims. The National Association of (State) Insurance Commissioners subsequently brought European regulators and insurance companies to participate in an International Commission on Holocaust Era Insurance Claims (ICHEIC). ${ }^{121}$ The Commission comprises state regulators and their European counterparts, as well as representatives of European insurance companies, public interest groups and the State of Israel. ${ }^{122}$ The U.S. State Department participates as an "observer," as do representatives of several other interested governments. ${ }^{123}$

In part due to the fact that these claims arise in the insurance sector, an area generally left to state regulation, the States have been able to participate significantly in addressing this international issue. Although the Congress might have preempted the States, it has chosen not to do so. Instead, the State Department strongly supported the state run Commission and prodded European insurers to cooperate with the ICHEIC to

119. See John Authers, Holocaust Pressure on Germany, Fin. Times (London), Jan. 2, 1999, at 3 .

120. See, e.g., Associated Press, Fed Clears a Planned U.S.-German Bank Merger, N.Y. Times, May 21, 1999, at C22; Roger Cohen, German Companies Adopt Fund for Slave Laborers Under Nazis, N.Y. TIMEs, Feb. 17, 1999, at A1.

121. See Lisa S. Howard, Holocaust-Era Claims Dispute Kills Re Deal, NAT'L UNderwriter (Life \& Health/Fin. Services Edition), Aug. 21, 2000, at 1; David E. Sanger, U.S. Shifts From Nazi Gold To Art, Land and Insurance, N.Y. Times, Dec. 1, 1998, at A6; Richard Wolffe, European Insurers Set to Unveil Deal on Holocaust Payments, Fin. Times (London), July 21, 1999, at 14.

122. See John M. Goshko, Holocaust Panel Tries to Enlist Eagleburger as Chairman, Wash. Post, Oct. 22, 1998, at A33.

123. See Press Release, International Holocaust Era Insurance Commission Launches Worldwide Outreach to Unpaid Policy Claimants (Feb. 16, 2000), available at http://www.icheic.org/eng/press.html (last visited Nov. 8, 2001). 
reach a settlement of the claims. ${ }^{124}$ State influence grew beyond what was acceptable to the Executive Branch, when California subsequently enacted a law requiring European insurers to disclose certain information. But even the State Department's opposition to this increased state pressure ${ }^{125}$ did not lead Congress to intervene. The federal government thus has not authoritatively stepped in to declare a particular national policy with which the state actions conflict. Nor has the Supreme Court's decision in Crosby led to outright preemption of state efforts. ${ }^{126}$ In short, the dialogue on this issue between the States and the federal government is still in progress.

\section{Summary}

Within the broad range of activities described above, it would be difficult to cordon off any particular realm as being without potentially serious implications for the foreign relations interests of the Nation as a whole. Although one might attempt to draw distinctions between diplomatic negotiations with foreign sovereigns and other forms of action, ${ }^{127}$ or between "proprietary" activity and "regulatory" activity, ${ }^{128}$ such distinctions are unlikely to track the boundaries of the national interest on the international scene. Similarly, distinctions between "private" matters such as trade and investment, and "public" matters such as environmental, health and human rights regulation, do not lead to successfully differentiating between those matters that affect U.S. foreign policy interests and those that do not.

Ivo Duchacek refers to many of these activities on the part of subnational units of government as "paradiplomacy:"

If by diplomatic negotiation we mean processes by which governments relate their conflicting interests to common ones, there is, conceptually, no real difference between paradiplomacy and traditional diplomacy: the aim is to negotiate and implement an agreement based on considered mutuality. Both sides pledge a certain mode of future behavior on the condition that the opposite side act in accordance with its promise. ${ }^{129}$

124. See Stuart E. Eizenstat, Deputy Treasury Secretary, Testimony Before the House Banking Committee (Feb. 9, 2000) (on file with author); see also Aegon Singled Out for Criticism On Holocaust Stance, FED. \& Sr. Ins. WK., Feb. 14, 2000, n.p.

125. See Colum Lynch, California Faulted On Holocaust Cases; Law's Effect on U.S. Efforts Decried, WASH. Post, Dec. 2, 1999, at A35.

126. See generally Gerling Global Reinsurance Corp. v. Low, 240 F.3d 739 (9th Cir. 2001) (upholding California's Holocaust Victim Insurance Relief Act).

127. See Swaine, Negotiating Federalism, supra note 1, at 1237-45.

128. This approach appears in several areas of constitutional law. See generally Garcia v. San Antonio Metro. Transit Auth., 469 U.S. 528 (1985) (holding that states are subject to laws generally applicable to public and private actors); Hughes v. Alexandria Scrap Corp., 426 U.S. 794 (1976) (stating market participant exception in dormant Commerce Clause jurisprudence).

129. Duchacek, International Dimension, supra note 80, at 16. 
If the conduct of diplomacy includes not only the conclusion of agreements but also unilaterally influencing other nations' behavior, then we may understand almost the entire range of actions described above as paradiplomacy as well. Accordingly, any project of defining a particular subcategory of this vast range of activity as being the stuff of "real" foreign relations is likely to be highly elusive. ${ }^{130}$ In one way or another, all these actions, from the promotion of trade and investment opportunities to the more explicitly "political" initiatives, may implicate the foreign relations interests of the Nation as a whole. ${ }^{131}$

The pervasive influence that these various actions have on the $\mathrm{Na}$ tion's foreign affairs, however, cannot be cast only in terms of the potential harm that they inflict. Instead, these initiatives also may have a positive

130. In addition to the acts of paradiplomacy reviewed here, there is a multitude of subnational activity that might not even be directed specifically toward influencing our Nation's foreign affairs, but that affects our foreign policy nonetheless. One of the classic historical examples is South Carolina's law imprisoning black seamen, which was not specifically directed at influencing our Nation's foreign policy or the policies of any foreign state. The law violated a U.S.-British treaty, but the federal government failed to take action to enforce the provisions of the treaty against the State. Ultimately, Great Britain negotiated with South Carolina and other southern States for a change in policy and the release of British subjects. See W. Brooke Graves, American Intergovernmentral Relations 368-69 (1964) (describing South Carolina act that would imprison any black sailors entering its ports). Justice Johnson, riding circuit, opined that these state laws were unconstitutional, but refrained from entering a judgment because he thought the petitioner in the case lacked a remedy. See Elksion v. Deliesseline, 8 F. Cas. 493, 497 (1823) (No. 4366). Similarly, a host of state taxes and regulations, such as California's unitary corporate tax and state "buy-American" provisions, have significant international ramifications. See generally Barclays Bank PLC v. Franchise Tax Bd., 512 U.S. 298 (1994); see also Brannon P. Denning \& Jack H. McCall, Jr., The Constitutionality of State and Local "Sanctions" Against Foreign Countries: Affairs of State, States' Affairs, or a Sorry Stale of Affairs?, 26 HASTINcs CoNST. L.Q. 307, 366-68 (addressing constitutional history of "buy-American" statutes). Less clearly belonging in this category, although with potential foreign policy implications as well, are the actions of over 120 cities, which have declared themselves to be nuclear free zones. See FrY, supra note 68, at 93.

131. Indeed, Crosby illustrates some of these features well. Although ostensibly a procurement decision, it was aimed at addressing an international issue. According to domestic jurisprudence, the state law may actually have overstepped the bounds of proprietary action, in that it included what was essentially a secondary boycott. See Alisa B. Klein \& Mark B. Stern, Back to First Principles: The Constitutional Rationale for Invalidating Local Sanctions Against Foreign Trade, 33 LAW \& POL'Y INT'L Bus. (forthcoming Fall 2001). Yet this particular feature of Massachusetts' action was irrelevant to the Supreme Court. And this feature was likely irrelevant to the alleged GATT (WTO) violation as well. To be sure, the absence of a secondary boycott would likely have significantly diminished the EU's and Japan's interests in the matter, but it would not have affected the alleged violation of the GATT (WTO) agreement. See Christopher McCrudden, International Economic Law and the Pursuit of Human Rights: A Framework for Discussion of the Legality of "Selective Purchasing Laws Under the WTO Government Procurement Agreement, 2 J. OF INT'L. EcoN. L. 3, 23-27 (1999). Finally, although the Massachusetts law led to "diplomatic" contacts between the state executive and foreign emissaries, unconditional unilateral action on the part of the State without any willingness to discuss the matter with foreigners would have exercised the objecting parties just the same. 
impact on the national foreign policy making process. Perhaps ironically, this positive impact is more apparent where state and local officials direct their actions specifically toward the conduct of the Nation's foreign affairs. By challenging the absence of federal foreign policy on an issue, state and local actors may raise national awareness of an issue, place issues on the agenda of federal officials or even induce the federal government to take action on behalf of the Nation. As the next section will show, in the foreign trade arena the federal government has seized upon some of these and other benefits of state and local involvement in an effort to turn them to the advantage of the Nation as a whole.

\section{Federal Inclusion of State and Local Governments in Foreign Policy Making}

Most Administrations in recent times have fostered the rising state involvement in foreign economic matters described above. ${ }^{132}$ Similarly, the Congress has increasingly provided a role for States and their representatives in foreign affairs. This federal hospitality to state participation represents, in part, a response to States' successful domestic lobbying activities, and, in part, an attempt to draw upon the States for resources, expertise, and strategic political support. These mutually reinforcing aspects of the federal-state relationship have propelled expanded federal efforts to include the States in the development of foreign policy in the international economic arena.

For example, the federal government originally included the States in promoting exports as a means to compensate for resource limitations at the federal level. ${ }^{133}$ Once President Carter created the standing committee of the National Governors' Association (NGA) on International Trade and Foreign Relations, ${ }^{134}$ however, the NGA, the committee and several other subnational inter-governmental organizations proved to be a formidable congressional lobby with regard to foreign policy initiatives more generally. ${ }^{135}$ The NGA committee in particular capitalized on the experi-

132. See Kline, State Government, supra note 66, at 71 ("Perhaps somewhat surprisingly, the overall relationship between state and national programs has nevertheless been generally very cooperative.").

133. See id. at 71 (noting that federal government initiated such state involvement to "help offset financial and other resource limitations" of federal government) (citing Council of State Governments, State Government Conducted International Trade and Business Development Programs, Techinical Study REPORT 13 (Nat'l Technical Info. Serv. 1977)).

134. See Kincaid, supra note 81 , at 103; see also Kline, State Government, supra note 66 , at 110 .

135. See Kincaid, supra note 81 , at 103; see also Kujne, State Government, supra note 66, at 43-45 (describing National Association of State Development Agencies, Federation of Tax Administrators, and Multistate Tax Commission). For an early description of this trend, see generally DONALD H. HAIDER, WHEN GOVERNMENTS COME To WASHINGTON (1974) (discussing nine case studies on local-state lobbying groups). In recognition of these successes, the federal government has increasingly sought to preempt state criticism by addressing local concerns about 
ence, knowledge, and connection to business interests that it enjoyed by virtue of the States' extensive record in export promotion activities. In its inaugural lobbying victory, it used these resources to shape significantly the reform of the Export Administration Act in the late 1970s. ${ }^{136}$

Despite the added power that state lobbying groups derive from federal recognition, Congress and the President have continued to encourage state participation in foreign affairs by expanding formal channels of subnational participation. In 1984, for example, Congress authorized the creation of what became the Intergovernmental Advisory Committee on Trade (IGPAC), ${ }^{137}$ which the U.S. Trade Representative (USTR) promptly convened "to provide overall policy advice on trade matters that have a significant relationship to the affairs of state and local governments within the jurisdiction of the U.S." 38 IGPAC was created at a time when international trading partners had repeatedly criticized the federal government for the States' unwillingness to submit to international trade regimes. At the same time, the United States was about to enter the Uruguay Round negotiations under the GATT, which promised to heighten these concerns. The Uruguay Round would implicate state concerns significantly more than did previous trade negotiations, ${ }^{139}$ and would further

the local ramifications of international agreements. See Charles Tiefer, Free Trade Agreements and the New Federalism, 7 Minn. J. Global Trade 45, 61-63 (1998).

136. See Kline, State Government, supra note 66, at 111-16. Only a few years later, a further prominent episode of significant subnational influence on an issue of foreign relations occurred when several States, led by California, Alaska, and Oregon, and assisted by the Multistate Tax Commission and the National Association of Tax Administrators, waged a successful domestic battle to defeat the provision of a U.S.-UK tax treaty that would have restricted the States' use of a particular method of taxing foreign-owned businesses. See id. at 127-55. The constitutionality of the Multistate Tax Commission was challenged, unsuccessfully, in the Supreme Court. See United States Steel Corp. v. Multistate Tax Comm'n, 434 U.S. 452 (1978).

137. Trade and Tariff Act of 1984, Pub. L. No. 98-573, ? 306(c) (2) (B) (ii) (3), 98 Stat. 2948 (1984) ("The President . . . may establish policy advisory committees representing non-Federal governmental interests."). The legislative history of this section states, "It is the committee's intention that these intergovernmental advisory committees be established and utilized only in the areas, like insurance or procurement, where the states have particular interests and not across the broad spectrum of trade issues." S. REP. No. 98-308, at 49 (1983).

138. Charter of the Intergovernmental Policy Advisory Committee on Trade If 1, at http://www.ustr.gov/ (last visited Sept. 1, 2001). The committee consists of thirty to forty appointed representatives of various state and local governmental entities across the Nation. See Matthew Schaefer, Searching for Parelo Gains in the Relationship Between Free Trade and Federalism: Revisiting the NAFTA, Eying the FTAA, 23 CAN.-U.S. L.J. 441, 481 (1997) [hereinafter Schaefer, Pareto Gains] (discussing creation and role of IGPAC).

139. See David W. Leebron, Implementation of the Uruguay Round Results in the U.S., in Implementing the Uruguay Round 175, 226 (John H. Jackson \& Alan O. Sykes eds., 1997) (noting that "for the first time, certain items in the schedules of commitments impose direct obligations on the states); Matthew Schaefer, TwentyFirst Century Trade Negotiations, the US Constitution, and the Elimination of State-Level Protectionism, 2 J. INT'L ECON. L. 71, 76 (1999) [hereinafter Schaefer, State-Level 
strengthen the U.S. commitment to bear responsibility for GATT violations resulting from subnational government action. ${ }^{140}$ The States were accordingly concerned about the agreement, particularly regarding its implications for services and government procurement. ${ }^{141}$

The IGPAC, however, represented only the beginning of States' inclusion in the process of trade negotiation. Fears about intrusion into state regulatory autonomy were heightened when, during the Uruguay Round of negotiations, Canada brought a successful suit against the U.S. before a GATT tribunal, which declared that the United States had violated its obligations under the agreement by virtue of taxes and other discriminatory burdens that States had placed on imported alcoholic beverages. ${ }^{142}$ To alleviate state concerns that the GATT would infringe on state autonomy, the Executive Branch specifically included state representatives in the subsequent negotiations of the GATT procurement code and integrated them into federal decision making regarding the implementation and future development of the GATT agreement. ${ }^{143}$ The federal government even negotiated for a limitation of the code to cover only the thirty-seven States that had declared their willingness to participate. It also worked closely with the National Association of State Procurement Officers (NASPO) to lessen the administrative burden that such an agreement would ultimately place upon the States, and negotiated for the inclusion of an annex listing specific procurement decisions exempted even in the case of participating States. ${ }^{144}$ As one commentator put it: "The President was not imposing international obligations on hapless states. Rather, he was gathering states' concessions and then, almost as a spokesman for a league of sovereigns, was presenting to other nations what the American states had offered." 145 Having presumably rejected the political feasibility of simply exercising its formal powers and forcing all the States to accept the procurement code, the President and Congress decided to work with the States rather than against them:

Protectionism] (noting that Tokyo Round agreements "impacted states either little or not at all").

140. See Leebron, supra note 139, at 226 \& n.195 (quoting GATT Art. XXIV:12-14).

141. For a review of the impact of the GATS on state law, see generally Jeffry Clay Clark, The U.S. Proposal for a General Agreement on Trade in Services and Its Preemption of Inconsistent State Law, 15 B.C. INT'L \& CoMP. L. REv. 75 (1992).

142. See U.S. Tells GATT It Will Not Block Adoption of Canadian Beer Report, 9 Int'1 Trade Rep. (BNA), No. 26, at 1083 (June 24, 1992) (reporting that U.S. will not oppose GATT decision upholding Canadian complaint that U.S. is imposing unfair duties on Canadian beer).

143. See Leebron, supra note 139, at 228; Schaefer, Pareto Gains, supra note 138, at 472. In 1988 Congress had also added non-federal government representatives to the forty-five-member Advisory Committee for Trade Policy and Negotiations, Omnibus Trade and Competitiveness Act of $1988 \S 135,19$ U.S.C. $\$ 2155$ (b)(1). See Leebron, supra note 139, at 224-31.

144. See Schaefer, Pareto Gains, supra note 138, at 472.

145. Tiefer, supra note 135 , at 61 . 
The 1994 Uruguay Round Agreements Act further requires the USTR to keep the States informed, allow for state input, and take the advice of state representatives into account when developing U.S. policy under the GATT. ${ }^{146}$ Moreover, Congress required that when a foreign government brings a claim against the United States due to actions of a State, the USTR should notify that State and allow it to participate in the resolution of the dispute. 147 Congress preempted all private causes of action challenging the validity of state laws based on a conflict with the GATT and consolidated any litigation against a State challenging GATT violations in the hands of the U.S. Attorney General. ${ }^{148}$ In a further gesture of conciliation and cooperation, the legislative history notes that litigation on the part of the Attorney General will be used only "as a "last resort," 149 noting that the Administration would "cooperat[e]" with the States in the implementation of the agreement. ${ }^{150}$ Finally, the USTR must notify, and receive advice from, the States before bringing a complaint before the WTO against a foreign subnational unit of government. ${ }^{151}$ To assist in this cooperation with the States, the USTR committed to appointing an official responsible for coordinating state matters and to working with a state point of contact in each State. ${ }^{152}$ Similar provisions govern with regard to the North American Free Trade Agreement (NAFTA). ${ }^{153}$

146. See 19 U.S.C. $\$ 3512$ (b) (1)(B)(i)-(iii) (1994). The legislative history further indicates:

[T]he President shall consult with the states, through the intergovernmental trade policy advisory committees established under section 306 of the Trade and Tariff Act of 1984, to achieve conformity of State laws and practices with the agreements . . . The U.S. Trade Representative (USTR) shall establish within the Office of the USTR a Federal-State consultation process for addressing issues relating to the agreements that directly relate to, or will potentially have a direct impact on, the states. This process will include procedures under which (1) the states will be informed on a continuing basis of matters under the agreements that directly relate to, or will potentially have a direct impact on, the State; (2) the states will be provided an opportunity to submit information and advice to the USTR on a continuing basis concerning these matters; and (3) the USTR will take into account the information and advice received from the states when formulating U.S. positions regarding these matters.

H.R. ReP. No. 826(I), at reprinted in 1995 U.S.C.C.A.N. 3773, 3795-96.

147. See 19 U.S.C. $\$ 3512$ (b) (1) (C).

148. See 19 U.S.C. $\$ 3512$ (b) (2) (B) \& (c) (1) (A)-(B).

149. 1994 U.S.C.C.A.N. 4013, 4050-54, 140 CoNG. REC. H15,036 (1994).

150. Id. at 4029.

151. See 19 U.S.C. $\$ 3512$ (b) (1)(D).

152. See Statement of Administrative Action, 15-16, 1994 U.S.C.C.A.N. at 4051; see also Leebron, supra note 139, at 228.

153. With regard to the NAFTA, Congress provided for parallel provisions of state consultation and protection and here, too, state representatives have attended meetings of committees that had been traditionally closed to representatives of subnational units of government. See 19 U.S.C. \$ 3312. Some NAFTA provisions are even more explicit regarding general state consultation. See, e.g., 19 U.S.C. \$3312(b)(1)(B) (v)(1994) ("[T]he States will be involved (including involvement through the inclusion of appropriate representatives of the states) to 
In 1999, the Clinton Administration's creation of the Office of Intergovernmental Affairs and Public Liaison (IAPL) further extended the involvement of state representatives in the formation of national policy on international economic issues. The IAPL was intended to serve, in part, to "expand and enhance USTR's partnership with and outreach to state and local governments" with regard to the World Trade Organization (WTO) agreement and the NAFTA. ${ }^{154}$ The IAPL coordinates the USTR's outreach to state and local governments (as well as the private sector), working with, among others, the IGPAC, the President's Advisory Committee on Trade Policy and Negotiations (ACTPN), several sectoral advisory bodies, fifty state points of contact designated by the governors' offices of each State, the National Governors Association, Western Governors Association, National Conference of State Legislatures, National Association of Attorneys General, and U.S. Conference of Mayors. ${ }^{155}$ Indeed, several state representatives have served as official members of U.S. delegations to the WTO ministerial level talks. ${ }^{156}$

Involving the States does not invariably mean giving way to isolationist pressures. To the contrary, in addition to the extensive international engagement described above, an overwhelming majority of state governors supported NAFTA, the Uruguay Round Agreements and the President's "fast-track" authority. ${ }^{157}$ Even when the Executive Branch has "imposed" a

the greatest extent practicable at each stage of the development of U.S. positions regarding matters [under the Agreement that directly relate to, or will potentially have a direct impact on, the States, and ] . . that will be addressed by committees, subcommittees, or working groups established under the Agreement or through dispute settlement processes provided for under the Agreement."); see also Schaefer, Pareto Gains, supra note 138, at 485-86. Congress also preempted any private right of action under NAFTA. See 19 U.S.C. $\$ 3312(\mathrm{c})$.

154. USTR 1999 ANNUAL. REPORT 304, available at www.ustr.gov/reports/nte/ 2000/vii.pdf (providing executive summary of trade policy development). IAPL is also in charge of outreach to the private sector, which was formally required by the Trade Act of 1974. IAPL is also in charge of outreach to the private sector, which was formally required by the Trade Act of 1974. For a discussion of private sector participation in the formulation of trade policy, see Leebron, supra note 139, at 197-201.

155. See USTR 1999 AnNUal Report, supra note 154, at 304-08; see also USTR Outreach: Trade $\mathcal{E}$ State and Local Governments, available at www.ustr.gov/outreach/ localgovs.html.

156. See USTR 1999 ANNUAL RePorT, supra note 154, at 308.

157. FRY, supra note 68 , at 108-09. Earlier, however, there had been a significant "Buy American" movement among U.S. state and local legislatures and executives. See Kline, State Government, supra note 66, at 87-91. Some courts held that such laws were unconstitutional under Zschernig. See e.g., Bethlehem Steel Corp. v. Bd. of Comm'ns, 276 Cal. App. 2d 221 (1969) ("The California Buy American Act, in effectively placing an embargo on foreign products, amounts to a usurpation by this state of the power of the federal government to conduct foreign trade policy."). Some later courts, however, were more willing to accept such laws provided the statutes themselves refrained from discriminating against foreign trade on the basis of the internal policies of other governments. See Trojan Techs., Inc. v. Pennsylvania, 742 F. Supp. 900, 913 (M.D. Pa.), aff'd 916 F.2d 903 (3d Cir. 1990) ("The Pennsylvania statute exhibits none of the dangers attendant on the 
National trade policy on the States, it is not infrequently acting as a "mediator" and "broker" among different state interests, with pro-trade States specifically seeking the assistance of the National government to effectuate international trade liberalization. ${ }^{158}$

Similarly, the NGA did not oppose an international agreement on government procurement, but instead passed a resolution urging States to maintain nondiscriminatory purchasing practices that would conform to the proposed procurement code. ${ }^{159}$ States have subsequently registered concern about the specific form of the agreement, argued for so-called "grandfather" clauses to exempt existing state legislation and been critical about the potential for intrusion into state affairs, particularly at the behest of individual litigants. ${ }^{160}$ As a general matter, however, at least as far as trade is concerned, States are willing to engage and to do so within the framework of federally negotiated trade agreements. Indeed, a recent NGA position paper declares: "The U.S. Trade Representative . . should negotiate new and expand existing trade agreements in an effort to achieve greater economic prosperity through global free trade."161 States' claims are frequently more about inclusion in, than outright opposition to, federal foreign policy initiatives in the trade area. ${ }^{162}$

statute reviewed in Zschernig, for Pennsylvania's statute provides no opportunity for state administrative officials or judges to comment on, let alone key their decisions to, the nature of foreign regimes."); Amarel v. Connell, 202 Cal. App. 3d 137 (1988); see also Nat'l Foreign Trade Council v. Natsios, 181 F.3d 38, 55-56 (1st Cir. 1999) (summarizing various state and local initiatives). With the rise of multilateral trade organizations, including NAFTA and the WTO, Congress has preempted individual claims against state laws that violate those agreements. See 19 U.S.C. $\$ 3512$ (b)(2)(a) \& (c). See generally Robert J. Delahunty, Federalism Beyond the Water's Edge: State Procurement Sanctions and Foreign Affairs, 37 Stan. J. INT'L L. 1 (2001).

158. This occurred, for example, when States along the Mexican border sought implementation of the NAFTA agreement on trucking Mexican goods into the United States. See Tiefer, supra note 135, at 62-63.

159. See Governors Adopt Resolutions Supporting NAFTA, GATT Procurement, 8 Int'l Trade Rep. (BNA), No. 34, at 1237 (Aug. 21, 1991) (reporting that NGA reaffirmed support for NAFTA); see also Tiefer, supra note 135, at 61.

160. See 140 Cong. Rec. S8853 (daily ed. July 13, 1994); see also Leebron, supra note 139 , at $227-28$.

161. Governors' Federal Legislative Priorities for the First Session of the 107th Congress, 2001, Feb. 27, 2001, available at http://www.nga.org/nga/legislativeUpdate/ 1,1169,C_ISSUE_Brieg\%5ED_1404,00.html.

162. See, e.g., Leebron, supra note 139, at 227 (noting Governor Tommy Thompson's 1994 demand for state inclusion before the House Way and Means Committee); National Conference of State Legislatures, Free Trade and Federalism (July 2000), available al http://www.ncsl.org/statefed/agtrade.htm; National Governors Association, Governors' Principles on International Trade Policy (adopted as amended 1999), available at http://www.nga.org/nga/legislativeUpdate/ 1,1169,C_policy_position^^D_506,00.html; see also Kuine, STATE Government, supra note 66, at 122 (describing Governors' position regarding access to federal foreign policy process); $i d$. at 80 (reporting results of survey of States' dissatisfaction with federal trade policy). 
In the context of trade and investment agreements, then, a fruitful form of cooperation between federal and state actors has emerged. The States, of course, gain influence by such inclusion in the federal decision making process, but the federal government benefits as well. By including the States, the federal government may draw upon State resources, such as information, experience, or funding, and increase the effectiveness of federal policy development and foreign negotiations. ${ }^{163}$ Working with state representatives also allows the federal government to draw upon a network for gathering political support for federal policies. Indeed the simple fact of inclusion or exclusion from the policymaking process may become a powerful tool of persuasion, as was the case with regard to the U.K.U.S. tax treaty, where States prominently and successfully used their exclusion from the negotiation process as an argument to lobby against ratification of the treaty in the Senate. ${ }^{164}$ State representatives, such as the NGA, are also particularly powerful mediators between the federal government and organized private interests. They are able effectively both to translate local and business concerns in a manner that does not raise suspicions of selfdealing, ${ }^{165}$ and to provide a valuable counterbalance to organized private pressure at the national level. ${ }^{166}$ Finally, given the political significance of state autonomy in Washington, federal policymakers are keen on developing foreign policies that can count on state support, and state inclusion in the federal policymaking process is a promising avenue of attaining that goal. ${ }^{167}$

In short, at least with regard to trade policy, the federal response to state involvement in foreign affairs has increasingly been to opt for a policy of constructive engagement rather than exclusion. Viewed from the perspective of state autonomy, this would simply be a welcome fact. Viewed from the perspective of the national benefits of state involvement,

163. Even beyond trade and investment, this has been true. For example, States have successfully participated in the negotiation of international wildlife treaties, where the federal government sought inclusion of the States especially due to their superior knowledge of implementation issues. See Kline, STATE GovERNMENT, supra note 66 , at $200-04$.

164. See id. at 141.

165. See id. at 218.

166. See id.

167. See, e.g., Kline, Intergovernmental Tensions, supra note 93, at 110 (noting federal government's general reluctance to impose direct obligations on state and local governments in the context of international agreements); id. at 111 (noting reluctance of federal government to sue States or preempt their sanctions against South Africa after federal government lifted its sanctions in 1991); Matthew Schaefer, The 'Grey Areas' and 'Yellow Zones' of Split Sovereignty Exposed by Globalization: Choosing Among Strategies of Avoidance, Cooperation, and Intrusion to Escape an Era of Misguided 'New Federalism', 24 CAN.-U.S. L.J. 35, 65 (1998). The federal government demonstrated a similar reluctance to intrude on state matters by refraining from ordering Virginia to postpone the execution of Angel Breard, even though the execution may well have placed the U.S. in breach of an international agreement. See Louis Henkin, Provisional Measures, U.S. Treaty Obligations, and the States, 92 Am. J. INT'L L. 679, 680-81 (1998). 
however, state engagement and inclusion need not be invariably desirable. Instead, the question remains how to structure state engagement to harness the positive contributions that state involvement in foreign affairs can make to the Nation as a whole without generating the disruptive elements that state participation can produce as well. The next section will put this question in comparative perspective.

\section{A Comparative Note on Federalism in Foreign Affairs}

Other federal systems have also struggled with managing a federal dynamic in foreign affairs. The experience of Germany and the European Union (EU) offers two illustrative examples. Both are divided power systems that have preserved the participation of the various levels of government in the conduct of foreign relations of the political system as a whole. Both have addressed the tensions between constituent state involvement and the ultimate need for a coherent foreign policy on the part of the overall system. And both have developed cooperative arrangements among central and constituent levels of government in the management of foreign relations.

In both the EU and in Germany, the problem of foreign affairs federalism has been mitigated by the imposition on various governmental actors of a duty of fidelity to the common enterprise. This may take the form of a duty of cooperation, involving consultation, joint participation, or coordination of action in foreign affairs, or it may involve restraint in action based on a more generalized duty of consideration of the interests of the overarching political system taken as a whole. The basic idea, which may be called "fidelity to the union" is the recognition of a duty to make the common enterprise succeed, and it is one that is deeply embedded in the jurisprudential theory of each of these systems. ${ }^{168}$

\section{A. Foreign Affairs Federalism in the European Union}

The founding treaties of the EU expressly recognize a general duty of cooperation on the part of the Member States to "facilitate the achievement of the Community's tasks."169 This duty serves to fill the gaps when

168. This idea of "fidelity to the union" differs from the related term used to describe a certain version of constitutional originalism in U.S. constitutional interpretation. See Lawrence Lessig, Translating Federalism: U.S. v. Lopez, 1995 SUP. Cr. REv. 125, 127 ("[I]f conventions in the original context were understood, but not said, and if they today are neither understood, nor said, then the response of fidelity is to articulate these previously understood conventions, and apply them today to assure that the constitutional structure original established is, so far as possible, preserved."); see also Lawrence Lessig, Fidelity and Constraint, 65 Fordram L. Rev. 1365 (1997). In the EU and in Germany, the idea of "fidelity to the Union" is a broader concept not necessarily linked to the preservation or "translation" of any original understanding of the founding charter, but rather a mutual duty of interinstitutional and inter-governmental cooperation and respect.

169. Treaty Establishing the European Community (TEC or EC Treaty), Nov. 10, 1997, art. 10, O.J. (C 340) 173. The Treaty states: 
Member State obligations are otherwise unclear and ordinary rules of hierarchy and preemption do not suffice to dispose of the tensions between Member State actions and Union interests. For example, when the EU passes a directive requiring the Member States to take certain action to implement EU policy, it generally allows for a period of time before the directive becomes effective. Although the Member States need not implement the Directive before its date of effectiveness, the European Court of Justice (ECJ) recently invoked Article 10's duty of cooperation to declare that Member States nonetheless must refrain from taking any affirmative action that would run contrary to the ultimate objectives of the directive. ${ }^{170}$ Thus, if the EU, for example, issued a directive prohibiting the hunting of a certain species of wild birds, a Member State that had always allowed such hunting would not need to limit it until the directive became effective. A Member State that already had such restrictions in place, however, would be prohibited from lifting the restrictions when the directive is announced even if that Member State intended to reinstate it when the directive became effective. The duty of fidelity also informed the ECJ's holding that where the Community has the exclusive power to regulate a given subject matter, and has failed to take affirmative action, Member States retain a residual power to act but in so acting, must heed the interests of the Community and act only as caretakers for the common interest. ${ }^{171}$

In the realm of foreign affairs, fidelity to the Union has played a particularly prominent role, especially in mediating issues of otherwise overlapping or fragmented authority and obligations. First, Member States must eliminate conflicts between their preexisting international obligations and their obligations under the EU Treaties (since the latter do not, as matter of EU law, trump the former). ${ }^{172}$ Thus, for example, Member State signatories to the century-old Rhine River accord worked together

\footnotetext{
Member States shall take all appropriate measures, whether general or particular, to ensure fulfillment of the obligations arising out of this Treaty or resulting from action taken by the institutions of the Community. They shall facilitate the achievement of the Community's tasks. They shall abstain from any measure which could jeopardize the attainment of the objectives of this Treaty.
} Id.

This duty is similar to, though not coextensive with, the international law duty of bona fides ("good faith") in carrying out treaty obligations. See, e.g., Armin von Bogdandy, Kommentar zu Artikel 5 EGV, in Eberhard Grabitz, Meinhard Hilf, Das RECHT DER EUROPÄISCHEN UNION (Maastrichter Fassung) (Looseleaf Sept. 1994) (suggesting difference between duty of cooperation under Article 5, now Article 10, of the EC Treaty, and obligation of bona fides in international law).

170. Case C-129/96, Inter-Environnement Wallonie ASBL v. Région Wallonne, 1997 ECR I-7411. 1045.

171. Case C-804/79, Commission v. United Kingdom (fisheries), 1981 E.C.R.

172. See EC Treaty art. 307 (formerly art. 234) ("To the extent that such agreements are not compatible with this Treaty, the Member State or States concerned shall take all appropriate steps to eliminate the incompatibilities estab- 
with the European Commission in renegotiating that treaty with Switzerland (the only non-EU member to the accord) in order to remove obstacles to the EU's transportation policies presented by the agreement. ${ }^{173}$ Second, Member States must cooperate with one another when exercising their remaining exclusive powers, such as the power to conduct foreign affairs in areas not covered by the EU Treaties. ${ }^{174}$

The potential for conflict stemming from federalism in foreign affairs in the EU is particularly acute because of the incomplete foreign affairs powers at the central level of government. ${ }^{175} \mathrm{EU}$ institutions have the power to conduct foreign affairs only with regard to specific (albeit rather broad) areas of substantive policy, while Member States retain the power over foreign relations with regard to everything else. Thus, only a combination of Member State and EU action will cover the entire field of foreign affairs. ${ }^{176}$ This consequence of the vertical division of authority was evident in the negotiation, ratification, and implementation of the GATT (WTO) agreements. For example, regarding the negotiation and conclusion of the WTO agreement, the ECJ held that while the Community had the exclusive power to conclude the GATT portion of that agreement, the power to conclude the GATS and TRIPs portions of the agreement was more complicated. ${ }^{177}$ Here, the court explained that the EU had the exclusive power to conclude some aspects of these agreements, notably those pertaining to cross-frontier supplies of services, while the Member States retained the exclusive power to conclude other aspects of the GATS and TRIPs, notably those portions dealing with consumption abroad, commercial presence of foreign subsidiaries, and entry of natural persons from WTO countries. The ECJ consequently held that the GATS and TRIPs portions of the WTO agreement must be signed not only by the EU or by its fifteen Member States individually, but by all sixteen parties: the EU plus its Member States.

The case arose after the negotiations had been completed, but before the treaty had been formally concluded. The European Commission had appealed to the ECJ for a ruling in favor of sole Community jurisdiction,

lished. Member States shall, where necessary, assist each other to this end and shall, where appropriate, adopt a common attitude.").

173. Opinion 1/76 (Laying-up fund), 1977 E.C.R. 741.

174. Case G-22/70, Commission v. Council (ERTA), 1971 E.C.R. 263.

175. For a broad comparative perspective on the divided foreign affairs system of the European Community, see Joseph H. H. Weiler, The External Legal Relations of Non-Unitary Actors: Mixity and the Federal Principle, in Mixed Acreements (David O'Keefe \& Henry G. Schermers eds., 1983).

176. Although in some cases the treaty allows for the ad hoc expansion of exclusive responsibility by a majority vote of the Member States, the general fragmentation of foreign affairs powers persists. See Sophie Meunier \& Kalypso Nicolaidis, Who Speaks for Europe? The Delegation of Trade Authority in the EU, $37 \mathrm{~J}$. Common MkT. STud. 477 (1999).

177. Opinion 1/94 (Uruguay Round Treaties), 1994 E.C.R. I-5267, 1 C.M.L.R. 205 (1995). 
in part to avoid such joint negotiations in the future. Most important, the Commission sought to avert problems that might arise in the administration of the agreement if the Community and the Member States were to share competence to conclude the GATS and TRIPs. The court, however, dismissed this concern, relying on the duty of cooperation to require that the various actors solve any such problems in a harmonious fashion. As the court noted, the various actors were under an obligation to cooperate not only in the negotiation and conclusion of the agreement, but also in the implementation of the agreement. For example, if the EU needed to take action (either to maintain its obligations or to retaliate against unfair trade practices of third party signatories), and such action required combined efforts covering areas subject to the Member State's exclusive jurisdiction, the Member States, according to the ECJ, would have to oblige. Cooperation is thus viewed as essential to combat the problems of otherwise fragmented power in the conduct of foreign affairs. As the European Court of Justice explained: "Th [e] obligation to cooperate flows from the requirement of unity in the international representation of the Community." 178

\section{B. Foreign Affairs Federalism in Germany}

In contrast to its European analogue, the German principle of Bundestreue (or "federal fidelity") does not appear in the text of the German Grundgesetz (GG) which is Germany's modern constitution. The idea, however, goes back at least to the German Constitution of 1871 and was elaborated during the early part of this Century by Rudolf Smend. ${ }^{179}$ Despite its lack of a textual foundation, the earliest decisions of modern Germany's Federal Constitutional Court (Bundesverfassungsgericht) relied on this concept, declaring federal fidelity to be a basic legal and justiciable principle requiring both affirmative cooperation and restraint whenever the common interest so demands. ${ }^{180}$

178. Id. I 108. Similarly, with regard to the Common Foreign and Security Policy, which is governed by the Treaty on European Union as opposed to the Treaty on European Community, Member States are required to "support the Union's external and security policy actively and unreservedly in a spirit of loyalty and mutual solidarity." Treaty on European Union art. 11. In addition, "Member States shall work together to enhance and develop their mutual political solidarity. They shall refrain from any action which is contrary to the interests of the Union or likely to impair its effectiveness as a cohesive force in international relations." Id.

179. See Rudolf Smend, Ungeschriebenes Verfassungsrecht im Monarchischen Bundesstaal, in FestSCHRIFT FŨR OTTO MAYER 247 (1916). For a treatment of Smend's reception in German constitutional theory, see STEFAN KorIoth, INTEGRATion und Bundesstaat: Ein Beitrag zur StaAts-und Verfassungslehre Rudolf Smends (Duncker \& Humblot eds., 1990).

180. See generally, David Currie, The Constitution of the Federal Republic of Germany 77-80 (1994); Donald P. Kommers, The Constitutional Jurisprudence of the Federal Republic of Germany $69-90$ (2d ed. 1997); Stefan Oeter, 
The idea of federal fidelity has been prominently developed as a reciprocal obligation on the part of the Federation (namely, the federal institutions of government) and the Länder (Germany's constituent states). For example, the Constitutional Court further objected to the Federation's creation of a television station not only because the action was beyond the Federation's authority to regulate the technical aspects of television frequency distribution and intruded into cultural matters, which are reserved to the Länder, but also because the Federation had violated the principle of fidelity by failing to consult with all the Länder before taking federal action. ${ }^{181}$ The Constitutional Court further illustrated the symmetry of this principle in the context of foreign affairs, by holding that the principle requires the Länder to consider the Federal Republic's international obligations when exercising their reserved powers, and that the Federation, in turn, must consult with the States before taking on obligations under international law whenever such obligations implicate the reserved powers of the Länder. ${ }^{182}$

Germany has recently reconsidered the question of how to preserve federalism in foreign affairs in the context of European Union matters. Here, the potential for conflict is particularly acute, because EU issues are formally considered foreign affairs matters and were thus, according to the German Grundgesetz, an exclusive prerogative of the federal government. In reality, however, EU affairs have long swept as broadly and penetrated as deeply as most any domestic policy agenda, thereby implicating many of the reserved powers of the Länder. Policy domains implicating the Länder's reserved powers had shifted away from the Länder legislatures, and away from the German federal legislature in which the Länder executives were at least directly represented, ${ }^{183}$ to the EU level where Germany was represented solely through its national Executive Branch Bundesregierung. Germany consequently had experienced difficulty in implementing EU matters pertaining to the reserved powers of the Länder. To resolve this tension, the Grundgesetz was amended in 1994 formally to include the Länder in the EU decision-making process and, at the same time, to affirm their duty to implement European directives. ${ }^{184}$ Article 23 GG now provides for a creative new scheme for Germany's representation in the EU, and a prominent role for the constitutional duty of cooperation in foreign affairs.

In its new version, Article 23 GG expressly guarantees that, as a general matter, in European Union affairs, "[t]he Bundesrat shall participate

INTEGRATION UND SUBSIDIARITÃT IM DEUTSCHEN BUNDESSTAATSRECHT 213-229 (Mohr Siebeck ed., 1998).

181. 12 BVerfGE 205, 254-56 (1961).

182. See 92 BverfGE 203 (1995); 6 BverfGE 309, 360-61 (1957).

183. The Länder executives sit in the German Bundesrat. See Art. 50 GG.

184. See generally Daniel Halberstam, Comparative Federalism and the Issue of Commandeering, in The Federal Vision: Legitimacy and Levels of Governance in the US AND THE EU 213, 242-244 (Kalypso Nicolaidis \& Robert Howse eds., 2001). 
in the decision-making process of the Federation insofar as the corresponding domestic decision would have involved [the Bundesrat] or insofar as the Länder would have had authority over the issue as a domestic matter."185 More specifically, Article 23 spells out three degrees of Länder involvement:

[1] Insofar as within matters of exclusive competence of the Federation, the interests of the Länder are affected, or the Federation otherwise has legislative power, the Federal Government must consider the position of the Bundesrat. [2] When the legislative powers, structure of agencies, or administrative procedures of the Länder are primarily affected, the Federation shall consider the Bundesrat's position as being decisive; in doing so, the responsibility of the Federation for the state as a whole is to be heeded.... [3] When the exclusive legislative powers of the Länder are primarily affected, the Federation shall delegate the exercise of the rights that the Federal Republic of Germany holds as a member of the European Union to a representative of the Länder designated by the Bundesrat. The rights are exercised with the participation and agreement of the Federal Executive; in doing so, the responsibility of the Federation for the state as a whole is to be heeded. ${ }^{186}$

According to reports evaluating these procedures, the coordination among the Federation and the Länder has worked reasonably well. ${ }^{187}$ The Federal Government has welcomed, and indeed fostered, the transfer of the powers of representation to a Länder representative, and the Länder representatives have successfully carried out their task of representing Germany in the EU Council. ${ }^{188}$ The involvement of Länder representatives appears not to have led to obstructionism on the part of Germany's Länder. For instance, the Länder were willing to compromise on the issue

185. Article 23 GG (as translated by author in consultation with David P. CuRrie, The Constitution of the Federal Republic of Germany (1994) and the International Constitutional Law website located at http://www.uni-wuerzburg.de/ law/gm00000_.html).

186. Id.

187. See, e.g., Gerd Blume \& Alexander Graf von Rex, Weiterentwicklung der Inhallichen und Personellen Mitwirkung der Länder in Angelegenheiten der EU nach

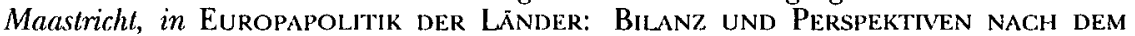
Gipfel von Amsterdam 29, 42 (Franz H.U. Borkenhagen ed., 1998) (noting positive cooperation during the 1996 European Intergovernmental Conference); RaLF Müller-Terpitz, Bundesrat und EuropÄIsche Union 353 (1999) (noting generally positive evaluation of cooperation process by participants); Lars von Dewitz, Der Bundesrat - Bilanz der Arbeit im EU Auscchu $\beta$ seit 1992, in Europapolitik der LÄNDER, supra (noting specific instances of successful cooperation); Georg-Berndt Oschatz \& Horst Risse, Die Bundesregierung an der Kette der Länder?, 1995 DAs ÖFFENTLICHE RECHT 437, 552 (noting that predicted difficulties have not been borne out in practice).

188. von Dewitz, supra note 187 , at 79-80. 
of EU local emergency measures, even though the Länder had initially charged that the proposed legislation exceeded the bounds of subsidiary enshrined in the Treaty. ${ }^{189}$

Germany thus has renewed its commitment to federalism in policy arenas with particular significance to its Länder, despite the fact that this domain has moved to the European Union level of governance and thus formally belongs to the realm of foreign affairs. The Constitution sets forth a detailed scheme for Länder involvement, and a duty of fidelity to the union tempers the potentially differing interests of the various institutional actors by committing them to heed the interests of the nation as a whole in exercising their respective powers.

\section{Lessons for the United States: What Positive Role for the States?}

Both the EU and Germany thus view the inclusion of constituent levels of governance as beneficial to the conduct of the overall system's foreign affairs. Both the EU and Germany have preserved a vertical division of powers, have formally included component units of government in the conduct of foreign affairs, and have required the various levels of government to cooperate in fulfillment of a constitutional duty of fidelity to the union. The following comparative discussion will consider whether heightened forms of federal-state cooperation are suitable for the United States, or whether other lessons for the United States may be drawn from this comparison.

In discussing the benefits of including the States in foreign affairs or imposing upon them a duty of cooperation with federal institutions of governance, it may be useful to distinguish between three different kinds of inclusion and cooperation. First is the idea of surrogacy. According to this view, the component states take action that the federal government would have taken, but cannot take itself. This dynamic permeates the basic structures of the EU and Germany. In each system the central government is incomplete in the sense that it cannot rely on a full array of legislative, judicial, and executive powers. The nuances of the central government's lack of power are different in the EU and in Germany, but in each system the central bureaucracy is relatively weak and must rely upon component units of government for assistance in virtually all aspects of governance. ${ }^{190}$ As the brief sketch of EU and German foreign policy powers demonstrated, here, too, those central governments lack a full complement of authority to govern. Under these circumstances, the component states' participation in governance fulfills a positive function for the nation as a whole, but it is a function that frequently does not add much beyond cost-sharing or making up for inadequate powers at the central

189. See generally id.

190. See generally, Halberstam, supra note 184. 
level of governance. ${ }^{191}$ To the extent that component states participating in governance must act as surrogates, their participation does not enrich the federal perspective. Such participation, then, is unlikely to further the national interest unless the central government is unable to act. Given that the United States is competent to act comprehensively with regard to foreign affairs, ${ }^{192}$ imposing a background requirement that States act as surrogates thus makes little sense.

At the other end of the spectrum is the vision of cooperation as a search for consensus prior to action. Involving component states in such a process substantially affects the policies adopted, and thus, to the extent that component states offer a distinct and valuable perspective, such inclusion would be beneficial to the national interest. Moreover, consensus may add legitimacy, as Hamilton noted when arguing for including the Senate as a check on the President's exercise of the treaty power. ${ }^{193}$ The general cost of consensus, however, is inefficiency of decision making and a strong bias in favor of the status quo. As Hamilton famously stated in

191. In Germany, for example, this distinction may be seen when comparing Lïnder activity under Articles 83, 86 and 75 GG. Under Articles 83 and $86 \mathrm{GG}$, the Lïnder act as surrogates of the federal government, in that they administer federal policies without substantive input. This is dramatically the case with regard to Article 86 GG, under which the Länder carry out Federation policy "as agents of the Federation," although even under Article 83 GG, according to which the Länder carry out Federation policy "as a matter of their own concern," the Länder enjoy only a modicum of control over the administrative procedures regarding the policy implementation. Only under Article 75 GG, which authorizes the Federation to pass framework legislation that the Länder must flesh out with their own laws, do the Länder exercise meaningful discretion in acting pursuant to federal norms. See generally, Halberstam, supra note 184. See also 2-3 Horst Dreiler, Grundcesetz Kommentar ArTs. 75, 83, 86 (1996). Although all three forms of participation are beneficial to the governance of the federal system, Länder assistance under Articles 83 and 86 GG could be obviated by enlarging the federal bureaucracy. Only the Article $75 \mathrm{GG}$ mechanism of framework legislation adds a distinct subnational perspective that could not otherwise be obtained. A similar difference exists in the EU when comparing regulations and detailed directives with so-called "framework directives," which are intended to leave the implementing Member State considerable latitude in filling the general Community norm with member state specific content. See Halberstam, supra note 184, at 230-34.

192. I put to one side the debate surrounding potential limitations on the federal government's treaty power. See Bradley, Trealy Power, supra note 1; Golove, Trealy Making, supra note 1, at 1076-77 (summarizing various positions within scholarly discourse).

193. With regard to making treaties, Hamilton conceded the wisdom of including at least the Senate as a check on the President's exercise of power. THE Federalist No. 75, at 505 (Alexander Hamilton) (Jacob E. Cooke ed., 1961). Hamilton stated:

The qualities elsewhere detailed, as indispensable in the management of foreign negotiations, point out the executive as the most fit agent in those transactions; while the vast importance of the trust, and the operation of treaties as laws, plead strongly for the participation of the whole or a part of the legislative body in the office of making them.

Id. For treatment of the Senate's role in this balance, see Ackerman \& Golove, supra note 1; Tribe, Taking Text and Simucture Seriously, supra note 1. 
arguing for a strong executive and against involvement of the large and varied House of Representatives in the treaty making process: "Decision, activity, secrecy, and dispatch will generally characterize the proceedings of one man, in a much more eminent degree, than the proceedings of any greater number; and in proportion as the number is increased, these qualities will be diminished." 194

This difficulty of weighing the cost of inefficiency against the added legitimacy of inclusion persists into the present. ${ }^{195}$ As Fritz Scharpf has noted with regard to EU and German decision making, cooperative arrangements requiring unanimity may lead to an inefficient "joint decision trap," which skews decisions by generally curtailing the ability to take action, as well as by occasionally inducing actions that appear cheaper than they are by virtue of the participation of the other party. ${ }^{196}$ To be sure, in the foreign affairs context, "inefficiency" may sometimes serve strategic purposes. ${ }^{197}$ Yet the greater the autonomy of central decision makers is

194. See The Federalist No. 70, at 472 (Alexander Hamilton) (Jacob E. Cooke ed., 1961); see also THE FEderalist No. 75, at 506-07 (invoking similar argument against inclusion of the House in formation of treaties).

195. See, e.g., Giovanni Sartori, Comparative Constitutional Engineering: AN INQUIRY INTO STRUCTURES, INCENTIVES AND OUTCOMES (1994) (propounding merits of "winner-take-all" electoral system); Arend Lijphart \& Bernard Grofman, Choosing an Electoral System, in Choosing an Electoral System: Issues and AlterNATIVES (Arend Lijphart \& Bernard Grofman eds., 1984) (arguing for greater legitimacy of proportional representation).

196. See Fritz W. Scharpf, The Joint-Decision Trap: Lessons from German Federalism and European Integration, 36 LAw \& ST. 1 (1987). See generally, Fritz W. Scharpf, Theorie der Politikverflechtung, in Scharpf et al., Politikverflechtung: Theorie und Empirie des Kooperativen Föderalismus in der Bundesrepublik 13-70 (1976).

197. See, e.g., Frederick W. Mayer, Managing Domestic Differences in Intermational Negotiations: The Strategic Use of Intermal Side-Payments, 46 INT'L Orc. 793, 796 (1992) ("Having one's hands tied can be quite useful in extracting concessions from an opponent in negotiation. U.S. negotiators, for example, have long used the threat of congressional rejection as a device for leveraging concessions at the bargaining table."); Putnam, supra note 65 , at 449 ("[T] wo level analysis . . implies that, ceteris paribus, the stronger a state is in terms of autonomy from domestic pressures, the weaker its relative bargaining position internationally"). An example of this phenomenon can be found in the maneuverings of the United States and European Community and its Member States after the breakdown of talks during the Hague Conference on Climate change in November, 2000. The U.S. sought to change the means for gauging fulfillment of treaty commitments under the Kyoto Protocol, to the opposition of the EU. John Prescott, Deputy Prime Minister of the United Kingdom, brokered an eleventh-hour compromise between the EU delegation and that of the United States. While the parties, as well as Mr. Prescott, initially believed they had reached an agreement, intra-European discord ultimately destroyed the deal. See Stephen Fidler \& Vanessa Houlder, Hague Talks Ministers Rally Behind French Colleague: 'No Agreement Better than a Bad Agreement' Say Portuguese, Fin. Times (London), Nov. 28, 2000, at 17. But see Andrew C. Revkin, Odd Culprits in Collapse of Climate Talks, N.Y. Times, Nov. 28, 2000, at F1 (blaming both sides for Hague failure). Due to the inefficiency of its internal decision making, the EU was thus able to preserve its initial policy decision, albeit at the cost of sacrificing an international agreement that would have included the United States. 
from their component state constituents, the larger the set of agreements that they might reach internationally, and the quicker they can respond to pressing issues. ${ }^{198}$ The EU has had much experience with such cooperation, both in the case of actual treaty negotiation and implementation, as well as in the case of more general foreign policy making. ${ }^{199}$ The requirement of unanimity for reaching decisions in Common Foreign and Security Policy (CFSP), for example, became the subject of widespread criticism in connection with the EU's response to the crisis in the former Yugoslavia. ${ }^{200}$ As a result, the Amsterdam Treaty lessened the need for cooperation under the CFSP so that individual Member States could, to a certain degree, opt out of EU-wide foreign and security policies. ${ }^{201}$

We should clearly be reluctant, then, to take lightly any broad based unanimity requirement as a precondition for taking action in the foreign policy arena. Extending the federal-state consultation process to require unanimity before exploring any further trade liberalization, for example, will slow down the development of further international agreements. An individual state veto may do so even if trade liberalization would be in the interests of the Nation as a whole. More generally, requiring consent at every step along the way introduces a certain path dependence that will further hamper reaching international agreements that may be beneficial to the Nation. ${ }^{202}$

Problems similar to those attending a unanimity requirement across constituent states, or among constituent states and the central government, may afflict policymaking conducted exclusively by the central government, particularly if conducted by a single large foreign policy bureaucracy. The same is true where authority for action is lodged in Congress, as Hamilton recognized long ago. If this is so, however, then the most significant contribution that States may make in their foreign

198. See, e.g., Putnam, supra note 65 , at 449.

199. See generally, Peter L. H. Van den Bossche, The European Community and the Uruguay Round Agreements, in ImPLementing the URuguay Round $66-69$ (John H. Jackson \& Alan O. Sykes eds., 1997). This experience in the foreign affairs arena mirrored the experience of the Community in domestic legislation where unanimity was widely required for any policy decision prior to the Single European Act. See generally Joseph H.H. Weiler, The Transformation of Europe, 100 YAl.E. L.J. 2403 (1991) (tracing history of unanimity requirement in EU).

200. See gemerally Paul Craic \& Grainne de Burca, EU law: Text, Cases, and Materials 39 (1998). See also William Bradford, The Western European Union, Yugoslavia, and the (Dis)Integration of the EU, The New Sick Man of Europe, 24 B.C. INT'L \& CoMP. L. Rev. 13 (2000).

201. See Treaty on European Union art. 23 (allowing Member States to issue formal declaration of dissent from EU policy, while noting that policy would still bind Union and that Member State would refrain from any actions that undermine policy).

202. In part, this is the idea behind creating "fast-track" authority, that is, preventing individual interests from voting down separate aspects of a trade liberalization package that, taken as a whole, will be in the interests of all. For a discussion of the history and development of "fast-track" authority, see Leebron, supra note 139 at $177-86$. 
policy initiatives, is helping the Nation to overcome this institutional inertia.

Between the poles of surrogacy and consensus, then, lies a third conception of "cooperation," imposed only in the ultimate outcome, but not along the way. The idea is that when States take actions, such as the recent initiatives surrounding the settlement of Holocaust claims, they provoke federal government action where such action may otherwise not have been forthcoming. It is far from clear that preserving the federal policy vacuum by a constitutional rule of state exclusion would have served the Nation as a whole, as some have argued. ${ }^{203}$ To the contrary, the fact that these settlements were ultimately pursued by federal negotiators, and publicly brought to a successful resolution with the apparent approval of the relevant national authorities, suggests that the States were not imposing any unjustified, sectoral interests on the Nation as a whole. Yet, this resolution may not have happened had it not been for the state regulators' initiative. More generally, then, domestic minorities (whether they be States or interest groups within States) may bring issues to the foreign relations table and ultimately win national support for them after the issue has run through the process of international bargaining and agreement. ${ }^{204}$ Requiring consensus at every step along the way, as well as excluding the States entirely, may hinder the emergence of an outcome preferred by all. In other words, the most significant benefit of constituent state involvement in foreign affairs is the ability to bring issues onto the national agenda that would otherwise lay dormant due to the inertia of decision makers within the national policy making bureaucracy. The benefit of state involvement in foreign affairs is neither mimicking the Nation as a whole, nor in reaching consensus at every step along the way, but in challenging the Nation to action.

\section{Doctrinal Consequences of a Positive Role for the States}

Recognizing such a benefit in state participation in foreign affairs clearly suggests a rejection of the categorical exclusion developed in Zschernig. Two further doctrinal consequences follow, however, from recognition of this positive state role: first, a rule of non-discrimination, and second, a rejection of any presumption regarding federal preemption and a concern for the preservation of positive federal policy.

The first rule is simple. Focusing on the national interest in state involvement in foreign affairs, a State's voice that seeks unfairly to advance its own interests to the inevitable detriment of its sister States would have little value. Inevitably, it will lead to disharmony and strife, and should be

203. See, e.g., Swaine, Foreign Relations Law, supra note 1, at 504.

204. For example, policy options may be created through international engagement that would not otherwise exist, thus altering the domestic political dynamic in favor or against any particular outcome. See Putnam, supra note 65 , at 447. If foreign engagement always depends on domestic consensus, these additional policy options might remain unexplored. 
presumed to be against the national interest unless proven to be otherwise by affirmative action of the federal political branches. The obligation of one component state not to discriminate against one's sister states in foreign policy issues is nicely illustrated by the European case surrounding the draft agreement for an insurance fund for waterway vessels on the Rhine and Moselle. ${ }^{205}$ The European Community lacked the authority to negotiate the necessary changes in the Rhine and Moselle river accords for the creation of the fund. Accordingly, the six Member States who were parties to those two agreements undertook the necessary negotiations with Switzerland, the only non-Member State party to the two accords. Although the participation of the six Member States in the external negotiations were thus justified in principle; the outcome was not. As the court described the flaws in the draft agreement,

[T] here are various groupings of those who are either given rights or placed under duties; sometimes all the Member States of the Community and Switzerland ... , sometimes the Member States, with one exception, and Switzerland ... , sometimes the Community as such and Switzerland ... and sometimes five States to which a special function is reserved in the decision-making process [of the resulting supervisory body]. ${ }^{206}$

In the court's view, this unevenness in rights and obligations was unacceptable, as it "alter[ed] in a manner inconsistent with the [EC] Treaty the relationships between Member States."207 The court held that the draft agreement could not be concluded because it was "not compatible with the requirements of unity and solidarity."208

United States Supreme Court decisions have imposed a similar nondiscrimination requirement on state activity in foreign affairs, although the context in which these cases arose has so far been largely limited to dormant Commerce Clause jurisprudence. As in dormant Interstate Commerce Clause jurisprudence, ${ }^{209}$ the Court has prohibited discrimination in deciding dormant Foreign Commerce Clause cases as well. In Michelin Tire Corp. v. Wages, ${ }^{210}$ for example, the Court moved beyond the formal inquiry whether the tires and tubes that were subject to a state property tax were "imports." Instead, the Court took a more functional approach,

205. Opinion 1/76 (Laying-up Fund), 1977 ECR 741.

206. See id. at 757 , I 9.

207. Id at $757, \S 10$. The Court also noted that the supervisory board appeared to shift power away from the Community and toward the participating Member States. See id. at 757 II 9-10.

208. Id at 758 , II 12 .

209. See generally Donald H. Regan, How to Think About the Federal Commerce Power and Incidentally Rewrite United States v. Lopez, 94 Mich. L. Rev. 554 (1995) [hereinafter Regan, How to Think About the Federal Commerce Power]; Donald H. Regan, The Supreme Court and State Protectionism: Making Sense of the Dormant Commerce Clause, 84 Mich. L. Rev. 1091 (1986).

210. 423 U.S. 276 (1976). 
examining whether the tax contravened the policies behind the constitutional provisions at issue. ${ }^{211}$ The Court identified one of these policies as an effort to preserve "harmony among the States[, which] might be disturbed unless seaboard States ... were prohibited from levying taxes on citizens of other States by taxing goods merely flowing through their ports to the other States not situated as favorably geographically." 212 In other words, States could not exploit their geographic monopoly with regard to the necessary flow of trade across its borders in a manner that would harm the interests of its sister States. The Court found that a nondiscriminatory ad valorem property tax, however, "unlike discriminatory state taxation against imported goods as imports, was not regarded as an impediment that severely hampered commerce or constituted a form of tribute by seaboard States to the disadvantage of the other States." 213 Moreover, such a tax reflected nothing else than the desire of the State to require the importer who, along with others doing business in the State, was a beneficiary of state services, to pay a fair share for the benefits thus conferred. ${ }^{214}$

Currently, however, the Court's decisions in the dormant Foreign Commerce Clause area go well beyond this basic idea of ensuring that state actions with foreign affairs implications are "fair" to their sister States' interests. With regard to state taxation of instrumentalities of foreign commerce, for example, the Court makes two additional inquiries. The first examines the "enhanced risk of multiple taxation," and the second asks whether the tax "may impair federal uniformity in an area where federal uniformity is essential." 115 Although the latter inquiry, properly understood, is justified from the national interest perspective on state participation in foreign affairs, the former is not.

For example, in Japan Line, which involved a nondiscriminatory ad valorem property tax on cargo containers, the Court explained that whereas domestically, apportionment could serve to guard against the dangers of multiple taxation, in the international context apportionment was insufficient to prevent multiple taxation. ${ }^{216}$ In the Court's view, the Court itself as well as the national political branches could, with regard to

211. Although the challenge was brought principally under the Import/Export Clause, U.S. Const. Article I, Section 10, Clause 2, the Court drew on dormant Foreign Commerce Clause analysis as well.

212. Michelin Tire, 423 U.S. at 285-86.

213. Id. at 286.

214. See id. at 288-89. The Court's reasoning in this case bears resemblance to its decisions in transportation cases under the dormant Commerce Clause. See, e.g., Kassel v. Consol. Freightways Corp., 450 U.S. 662 (1981). Its inquiry also strongly resembled the Court's dormant Interstate Commerce Clause analysis, which asks whether a tax is applied to an activity with a substantial nexus with the taxing State, is fairly apportioned, does not discriminate against interstate commerce, and is fairly related to the services provided by the State." Complete Auto Transit v. Brady, 430 U.S. 274, 279 (1977). (1979).

215. See Japan Line, Ltd. v. Los Angeles County, 441 U.S. 434, 446, 448

216. See id. at 448. 
domestic taxes, ultimately step in and ensure that each taxing authority fairly apportioned its share of taxes. When one of the taxing authorities is a foreign government, in contrast, this would be impossible. In Japan Line, the state tax resulted in actual multiple taxation, because California taxed certain shipping containers in part, while Japan taxed them in full. The Court could prevent such multiple taxation only by prohibiting California's partial (and arguably fair) state tax. In other words, as soon as a foreign state taxes an aspect of foreign commerce that might otherwise be subject to a fair state tax within the United States, the Court, under this rule, would ascribe exclusive domestic taxing power to Congress.

The Court's goal here is the eradication of multiple taxation of foreign commerce, since such taxation makes foreign commerce relatively more expensive than domestic (interstate) commerce. Such an uncompromising goal, however, does not square with the Court's domestic jurisprudence, where the Court has upheld fairly apportioned state taxes even when they create a real risk of multiple taxation. ${ }^{217}$ In Moorman Manufacturing Co. v. Bair, ${ }^{218}$ for example, the Court upheld an apportionment formula by one State, even though other States were using a different apportionment formula, and even though the use of such differing formulas would almost certainly lead to multiple taxation. Although the threat of multiple taxation may indeed be a legitimate concern, a State need only act fairly to fulfill its constitutional duty to avoid such excessive burdens to interstate commerce. If multiple taxation should be eradicated entirely, the Court ought not to tolerate such multiple taxation in the domestic context either. ${ }^{219}$ And if fairness guides the analysis of taxation of instrumentalities of interstate commerce domestically, ${ }^{220}$ then States should be able to prod the federal government into action by adopting a taxing scheme with international implications as long as they are being "fair" to their sister States here as well.

217. Even though the Court's domestic dormant Commerce Clause jurisprudence may demonstrate a concern about multiple taxation, the Court stopped short of prohibiting multiple taxation entirely and required only that States impose taxes that are "fairly apportioned." Cf. Regan, How to Think About the Federal Commerce Power, supra note 209, at 612-14 (arguing that Court's "fair apportionment" jurisprudence under dormant Interstate Commerce Clause is justified by concern about multiple taxation).

218. 437 U.S. 267,277 (1978).

219. The Court subsequently held that it accepts the possibility of multiple taxation in both contexts, but it has presented this as an exception to the general rule whenever the multiple taxation was not the "inevitable result" of the tax and where the "alternatives reasonably available" to the State did not eliminate the risk of multiple taxation. See Barclays Bank v. Franchise Tax Bd., 512 U.S. 298, 318-319 (1994); Container Corp. v. Franchise Tax Bd., 463 U.S. 159, 188-89, 191 (1983).

220. See Okla. Tax Comm'n v. Jefferson Lines, Inc., 514 U.S. 175, 184 (1995) ("The difficult question in this case is whether the tax is properly apportioned within the meaning of the second prong of Complete Auto's test, 'the central purpose [of which] is to ensure that each State taxes only its fair share of an interstate transaction.") (citation omitted). 
The Court's second additional inquiry (whether the state law "may impair federal uniformity in an area where federal uniformity is essential") coincides with the second doctrinal rule that I would like to explore here: the rejection of presumptions regarding preemption and a strong commitment to the preservation of positive federal policy. If we abandon the inherently skeptical view of state participation in foreign affairs, and we recognize that such state activity may benefit the Nation as a whole, it is difficult to make any assumptions about the likely intent of federal policymakers regarding preemption, and the main goal of preemption analysis becomes the vigorous protection of positive federal policy.

Expressing this simply as a rejection of presumptions regarding preemption, as some scholars have argued, ${ }^{221}$ is, however, incomplete. The metaphor of an evidentiary "presumption," or lack thereof may mean several things. First, it may refer to the default rule at the outset of the litigation, that is, declaring a winner when no relevant facts are proven, or to a "tie-breaker" that determines the outcome in those rare cases in which the evidence leaves the decision maker in equipoise. Used in this sense of a "litigation presumption," as one might call it, a presumption against preemption is a basic feature of our federal system in which state authority is general and federal power enumerated and particular. ${ }^{222}$ Without a showing that federal law preempts state law, the state law will stand. And should the rare case arise in which a judge is genuinely in equipoise regarding the federal political branches' intent concerning preemption, the state law will prevail as well. A presumption, however, may alternatively (albeit relatedly) denote a substantive default conclusion about the evidence, an assumption regarding the likelihood of a given evidentiary conclusion, or even a systematic bias coloring the interpretation of all the evidence received. ${ }^{223}$ Understood in this "evidentiary" sense, a "presumption against preemption," for example, might assume that Congress did not intend to preempt the States unless proven otherwise, that Congress is generally unlikely to have intended to displace the States, or that we are indeed so skeptical about any claim of preemption that interpretations suggesting Congress had the intent to preempt the States are disfavored whenever there are other minimally plausible constructions of the evidence. This evidentiary presumption against preemption may be based on

221. See generally Goldsmith, Statutory Foreign Affairs Preemption, supra note 1; see also Ernest A. Young, Dual Federalism, Concurrent Jurisdiction, and the Foreign Affairs Exception, 69 Geo. WASH. L. Rev. 139, 172 (2001). For a helpful discussion of the "presumption against preemption" and the view that the Supremacy Clause was intended to abolish any such presumption, see Caleb Nelson, Preemption, 86 VA. L. Rev. 225 (2000).

222. Cf. Goldsmith, Statutory Foreign Affairs Preemption, supra note 1, at 201.

223. Although a litigation presumption would tend to go hand in hand with an evidentiary presumption, the two are analytically distinct. One might believe that one party or another should win absent any facts being adduced, or that the tie should go to one party or another, without thereby making any corresponding substantive claims about the likely interpretation of the evidence itself. 
the view that States have traditionally regulated in this area and that the federal government is unlikely to have intended their displacement absent careful consideration of the issue. Conversely, an evidentiary presumption in favor of preemption might be based on the idea that Congress is likely to view state action in the foreign policy arena as trouble for the Nation.

Professor Goldsmith, who has recently argued for rejecting presumptions regarding preemption (at least in the foreign affairs context), is invoking this evidentiary sense of "presumption," that is, he rejects making substantive assumptions about what the federal political branches intended (or are likely to have intended), as well as harboring a systematic bias in favor of the States in the interpretive project as a whole. He agrees with the litigation presumptions that the State should win unless it is proven that federal law preempts, and that the State should also win in the rare case in which the facts concerning the federal policymakers' intent leave a court in equipoise. Beyond that, however, he urges judges to "perform preemption analysis without recourse to the presumptive cannons." ${ }^{224}$ As Goldsmith notes, because the evidentiary presumption against preemption (in matters of traditional state concern) faces an opposing evidentiary presumption in favor of preemption (in matters pertaining to foreign affairs), and because foreign affairs increasingly will overlap with matters of traditional state concern, "the competing presumptions against and for preemption lose coherence and usefulness." 225

Abandoning evidentiary presumptions and systematic interpretive biases in favor or against the States in examining the federal policymaker's intent regarding preemption makes sense from the perspective of the national benefits of state participation in foreign affairs as well. From this perspective, state action as a means to goad the federal government to action has fulfilled its beneficial role for the Nation once the federal policymaker has considered the issue. At the same time, however, continued state action may also be supportive of federal policy, and thus Congress should not be presumed to have excluded the States simply by virtue of acting. Accordingly, the only relevant question is whether the federal political branches have truly spoken to the issue raised by the States and whether the federal policy envisions a continued role for the States.

Rejecting these evidentiary presumptions regarding preemption, however, still leaves open questions about actually weighing the evidence. Even absent initial assumptions about the conclusions to be drawn and without any bias skewing the inquiry in a particular direction, indications of the federal policymaker's intent to preempt or preserve state participation in a given foreign policy matter may be weighed quite differently. At one extreme, seemingly minor expressions of intent (to preempt or preserve state action) might be minimized or discounted while more compelling evidence is sought; that is, a court might display considerable

224. Goldsmith, Statulory Foreign Affairs Preemption, supra note 1, at 200. 225. Id. at 197. 
hesitance to drawing any conclusion from scanty evidence regarding intent. Alternatively, such small indications of the federal policymaker's likely intent might be magnified and taken as sufficient to indicate an authoritative federal policy decision on the matter.

This is where the Court's approach evinces an eagerness to preserve positive federal policy (which is not, however, synonymous with a bias in favor of displacing the States). Once the federal policymaker has spoken to the issue, the Court demonstrates great solicitude towards the federal policy decision. In weighing the evidence regarding the federal policymaker's intent to preempt or preserve state law, the Court is willing to act on implications and seize upon rather subtle indications of intent. This heightened sensitivity to discerning what may lie beneath the formal promulgation of the federal policy, may work in the State's favor as well as against it. In short, in weighing the evidence regarding positive preemption, the Court's foreign policy lens magnifies implications of both preemption and preservation of state law.

On closer inspection, several of the Court's cases regarding "federal uniformity" and the maintenance of "one voice," bear this approach out. For example, we see this heightened interest in preserving positive federal policy already in Michelin Tire, which noted as an additional reason for upholding the nondiscriminatory state tax that it did not threaten U.S. policy. ${ }^{226}$ The state tax did not challenge the federal government's exclusive ability to regulate foreign commerce, because the tax could not "be applied selectively to encourage or discourage any importation in a manner inconsistent with federal regulation." 227 Michelin Tire thus shifted the focus not only toward the practical effect of the tax in terms of achieving interstate harmony, but also to whether it stood in tension with federal policies.

Even more to the point is Japan Line. More important than the threat of multiple taxation discussed above, is the theme of uniformity and the doctrine of "'speaking with one voice' in regulating foreign trade."228 In Japan Line, however, this does not entail the categorical exclusion of the States from the realm of foreign affairs. Instead, the Court specifically identifies a "national policy," which the state tax purportedly contravenes. The Court notes that the Customs Convention on Containers, which was signed by both the United States and Japan, evidences "the desirability of uniform treatment of containers used exclusively in foreign commerce."229 In addition to specifying that income derived from use of such containers should not be taxed twice, the Convention provides that containers temporarily brought into a signatory country "are admitted free of

226. See 423 U.S. 276 (1976).

227. Michelin Tïre, 423 U.S. at 286.

228. Japan Line, Ltd. v. County of Los Angeles, 441 U.S. 434, 452 (1979).

229. Id. 
'all duties and taxes whatsoever chargeable by reason of importation."'230 This, in the Court's view demonstrated a "national policy to remove impediments to the use of containers as 'instruments of international traffic." 231 And without holding that the Customs Convention on Containers or any act of Congress had formally preempted California's law, and without holding that there was a specific conflict created by adherence to the Convention and payment of California's tax, the Court decided that California's tax "will frustrate the attainment of federal uniformity."232

The threat that California's tax presents to uniformity is plain. Because Japan in fact did not tax American-owned containers located in Japan, California's tax created an "asymmetry" between the way containers were treated in Japan and California. ${ }^{233}$ This non-uniformity on the international plane had obvious ramifications regarding the potential imposition of retaliatory taxes or other countermeasures. But far more important, this (international, but not federal) lack of uniformity was in tension with the national commitment to international uniformity (at least among signatory states, which included Japan and the United States). In this sense, California frustrated the ability of the Nation to "speak with one voice" on the subject of taxing containers in international commerce, because it was in tension with the message that the United States had sent on behalf of the Nation as a whole. ${ }^{234}$

Such an enforcement of uniformity does not require the States to step back entirely. It merely imposes an obligation upon the States to heed a "national policy," even where that policy may not be expressed in a manner that would otherwise lead ordinary rules of preemption to prohibit the state practice in question. This, then, is the crux of the holding in Japan Line. First, the States are not entirely excluded from the foreign policy

230. Id. at 453.

231. Id.

232. Id.

233. Id.

234. The Court also noted that other States may impose their own taxes and thus contribute to a lack of uniformity in the method of taxation throughout the United States, with the result that "foreign-owned containers will be subjected to various degrees of multiple taxation, depending on which American ports they enter." Id. The concern with this lack of uniformity may be twofold. On the one hand, other States' taxation of foreign owned containers may further undermine the Nation's purported message that it intends to create an international regime of uniform treatment. This concern would simply be an extension of the concern about California's tax itself. On the other hand, the Court may view the lack of uniformity of taxation of foreign-owned containers to be itself a detriment to the Nation as whole. In other words, the Court may claim that uniformity across the Nation in the taxation of foreign commerce is itself a value. Given that the Court does not hold that the federal government's power to tax foreign commerce invariably preempts non-uniform state taxes falling on this terrain, the decision is best understood, as expressing only the first concern, i.e., that the potential existence of similar (though not identical) taxes imposed by other States further undermines the "national policy" of uniform international treatment reflected in the Customs Convention. 
realm by virtue of the federal government's action; second, they must, however, not compromise the federal government's policy on the treatment of foreign commerce; and third, we can discern a national policy even when it is only sketched out as a general principle that does not formally purport to stake out the field or otherwise preempt state regulation. ${ }^{235}$

Although Barclays Bank is sometimes viewed as having reversed the Court's position on state involvement in foreign commerce matters, the departure from Japan Line is somewhat less radical than may appear at first blush. If the Court's "one voice" jurisprudence is (mis) understood as being simply about creating uniformity across the United States in the taxation and regulation of foreign commerce, then Barclays Bank indeed stands for a quite significant departure from prior case law. If, on the other hand, the Court's "one voice" jurisprudence is understood as a doctrine of conformity of state actions with positive federal policy, then Barclays Bank reflects a far more modest departure, if it is a departure from prior case law at all.

As an initial matter, the tax at issue in Barclays Bank appeared to be both a common and fair approach to determining the portion of taxable income reasonably attributable to California. ${ }^{236}$ The Court did not require that California adhere to "international practice" in order to serve international uniformity or the interests of foreign nations that may lack access to the political process that created the tax. ${ }^{237}$ The crucial question for the Court was whether the tax frustrated uniformity "where federal uniformity is essential" and whether it undermined the federal government from "speaking with one voice."238

Although some passages in Barclays Bank read as though the Court is simply applying straightforward preemption rules and finding in this case that Congress simply lacked the intent to preempt California's franchise tax, ${ }^{239}$ the Court's decision is based on a different premise. Instead of

235. Cf. Itel Containers Int'l Corp. v. Huddleston, 507 U.S. 60, 71 (1993) (upholding sales tax on lease of cargo containers, noting that " $[\mathrm{t}]$ he precise federal policy regarding promotion of container use is satisfied by a proscription against taxes that are imposed upon, or discriminate against, the importation of containers").

236. As in Container Corp. v. Franchise Tax Bd., 463 U.S. 159 (1983), the Court was willing to sustain the tax despite the occurrence of multiple taxation because other reasonable alternatives would result in a similar risk. Thus, the Court was unwilling to require that California abandon its effort to tax the business simply because any such effort might result in duplicative taxes collected elsewhere. As noted above, see supra note 228 and accompanying text, this represents a modest easing of the multiple taxation inquiry in Japan Line, although it still differs from the corresponding inquiry under the dormant Interstate Commerce Clause.

237. See Barclays Bank v. Franchise Tax Bd., 512 U.S. 298, 320 (1994).

238. $I d$.

239. See, e.g., id. at 321, 324 (finding, as in Container Corporation, no "'specific indications of congressional intent' to bar the state action here.") (quoting Container Corp., 463 U.S. at 196-97); id. at 331 ("we leave it to Congress . . . to 
finding a lack of preemption, the Court ultimately based its decision on the view that Congress's inaction "implicitly . . . permitted the States" to use the reporting method at issue. ${ }^{240}$ As the Court noted, Congress had not enacted legislation in response to a prior, similar Court decision that had upheld the California franchise tax. Furthermore, Congress was undoubtedly aware of foreign governments' concerns about the state tax. And finally, the Senate had rejected one version of a treaty with the United Kingdom that would have restricted state taxation in favor of another version of the treaty that did not. ${ }^{241}$ The Court itself appeared to realize that these actions fell far short of what would, in a different context, count as intentional authorization. ${ }^{242}$ Again, however, it viewed the matter through its magnifying lens of foreign policy analysis, noting that an important premise underlying the decisions in this area of the law was that "Congress may more passively indicate that certain state practices do not 'impair federal uniformity in an area where federal uniformity is essential." 243 Put another way, the policy decision that emerged after the States prodded Congress to consider the question was not to exclude the States. And this policy decision, just as the one in Japan Line requiring state conformity, could be discerned even absent formal legislation regarding the question of preemption.

\section{Two REAdings of CROSBY}

The Supreme Court's decision in Crosby is thus susceptible to two readings, one suggesting strong federal exclusivity, and another signaling openness to state participation in foreign affairs.

On the one hand, Crosby may signal a return to the unyielding, singular voice in foreign relations matters based on old-style mistrust of the States. Several of Massachusetts' activities had not yet contravened federal law. For example, as one strike against the state law, the Court notes that Massachusetts' sanctions were permanent, whereas the federal measures were subject to change during the bargaining process with Burma. ${ }^{244}$ If the States can be trusted, however, this conflict should be ripe only when the federal government ends its sanctions and Massachusetts fails to follow suit. Similarly, the Court notes that the permanence of the state measures was in conflict with the President's power to end all sanctions whenever the national security interest so demanded. Here, too, a more state-

evaluate whether the national interest is best served by tax uniformity, or state autonomy").

240. Id. at 326 .

241. Id. at 324-27.

242. Cf. id. at 332 (Scalia, J., concurring in part and concurring in the judgment) (noting that opinion "restores the power [over foreign commerce] to Congress-albeit in a form that strangely permits it to be exercised by silence").

243. Id. at 323 (quoting Japan Line, Ltd. v. Los Angeles, 441 U.S. 434, 448 (1979))

244. See Crosby v. Nat'l Foreign Trade Council, 530 U.S. 363, 367 (2000). 
friendly approach might have deferred preemption until the State refused to rescind its sanctions when the President canceled the corresponding federal measures. With regard to these measures, one might complain that the decision excluded the States prematurely and without awaiting the federal articulation of a policy that the State was supposed to have contravened.

Yet that was, of course, not the only basis for the Court's decision. Taking the opinion as a whole, we may read the Court as carefully tracing the articulation of federal policy embodied by the statutory scheme. As in Hines, the decision struggles with the absence of any positive indication on the part of Congress that the federal scheme, enacted with full knowledge of the Massachusetts procurement law, intended to displace the States. ${ }^{245}$ Yet the Court does not resort to the presumption against State involvement in foreign affairs. Instead the Court extracts from the entirety of the statutory scheme that Congress intended to calibrate the overall force that would be brought to bear on Burma by authorizing specific sanctions and concentrating bargaining power in the President alone. This, then, was the positive articulation of federal policy. It did not include any specific expression regarding preemption, yet its purpose was in tension with continued state involvement. In that sense, Crosby appears to have rejected any presumption against preemption, despite the opinion's protestations to the contrary. And it was highly solicitous of preserving this positive federal policy, free from being compromised by the State.

In other words, by refraining from reaffirming Zschernig, the Court remained open to the idea that Massachusetts may have been justified in originally enacting the state Burma sanctions. And it may have remained so in the absence of federal action. But three months after Massachusetts brought the issue of sanctions against Burma onto the Nation's front pages, the federal government articulated a comprehensive national policy on the matter. ${ }^{246}$ To the extent that Massachusetts' continued pursuit of its state sanctions would now be upheld despite the tensions with federal policy, it could only be upheld as a matter of state autonomy. But as far as the national interest in state participation in foreign affairs was concerned, Massachusetts had already done its job.

245. Id. at 376,387 (noting that it is "simply implausible" that Congress would have "been willing" to allow States to compromise effectiveness of President's discretionary action); $i d$. at 388 ("[T] he silence of Congress is ambiguous").

246. For a treatment of the reaction of the federal government to the enactment of the Massachusetts law, see State and Local Trade Sanctions Trouble U.S. Trade Partners, Wall ST. J., Apr. 1, 1998, at A20; see also Leon T. Hadar, U.S. Sanctions Against Burma a Failure on All Fronts (Mar. 26, 1998), available at www.cato.org/ pubs/trade/tpa-001.html (tracing history of U.S. sanctions against Burma from state actions to Congress and Executive Branch). Whether the federal statute actually enacted was directly prompted by the Massachusetts law is somewhat unclear. See Bradley, New American Foreign Affairs Law, supra note 1, at 1099; Swaine, Crosby as Foreign Relations Law, supra note 1, at 484.n.10. 


\section{Conclusion}

The Court has repeatedly invoked the principle that "[i]n international relations and with respect to foreign intercourse and trade the people of the United States act through a single government with unified and adequate national power." ${ }^{47}$ As this Article has sought to demonstrate, this is not an accurate picture of federalism (or the lack thereof) in foreign affairs. Although the federal government may have the full complement of formal powers to act within the foreign affairs arena, it more than occasionally needs help in taking action and formulating federal policy. This help has increasingly come through state participation in matters affecting our foreign relations. State participation in foreign affairs may help counteract resource limitations at the federal level, provide expertise on foreign policy matters with significant local implications, mediate among competing interest groups and broaden political support for national initiatives, and spur the federal government into action. In cases of tension between federal and state policies, the latter benefit is particularly significant, and has accordingly been the primary focus of analysis here.

Thus, quite apart from any purported autonomy interest of the States, and apart from the usual consideration of the evils of state activities in foreign affairs, this Article has urged a different focus: the consideration of state participation as beneficial to the interests of the Nation as a whole. If one is concerned with national power and filled with utter distrust of the States, as the Court has been in early times, then a broad rule of dormant exclusion neatly follows. If one is solely concerned with state autonomy, then the point of displacing the States would naturally lie only at the point of affirmative formal preemption. But if, as this Article has suggested, we evaluate state participation with a view to its positive contribution to the national interest, a slightly different approach emerges. States should not be excluded from the foreign policy arena, but in stepping into that realm, States must not discriminate against their sister States, and they must heed national policy once articulated by the federal political branches. Thus, state participation is indeed beneficial, but only up to a point. That point is reached when the Nation has spoken to the issues raised and has chosen to exclude the States. According to the Court, that point had been reached in Crosby.

247. See, e.g., Bd. of Trs. v. United States, 289 U.S. 48, 59 (1933). 